\title{
Premodernity, Modernity, Postmodernity, and Eu-Modernity as the Four Stages of Civilizational Developmental Psychology: Comte's Parallel Human-Civilizational Developments
}

\author{
Dingyu Chung \\ Utica, MI, USA \\ Email:dy_chung@yahoo.com
}

How to cite this paper: Chung, D. (2020). Premodernity, Modernity, Postmodernity, and Eu-Modernity as the Four Stages of Civilizational Developmental Psychology: Comte's Parallel Human-Civilizational Developments. Advances in Applied Sociology, 10, 369-420. https://doi.org/10.4236/aasoci.2020.109023

Received: July 28, 2020

Accepted: September 18, 2020

Published: September 21, 2020

Copyright (อ 2020 by author(s) and Scientific Research Publishing Inc. This work is licensed under the Creative Commons Attribution International License (CC BY 4.0).

http://creativecommons.org/licenses/by/4.0/

(c) (i) Open Access

\begin{abstract}
In this paper, the Auguste Comte's parallel human-civilizational developments in the early nineteenth century are broadened and updated for the twentyfirst century. Comte establishes the parallel between European civilizational development as the law of three stages (the theological stage, the metaphysical stage, and the positive scientific stage) and human development (childhood, adolescence, and adulthood). He holds that each individual human develops from the stage of a devout believer in childhood as in the theological stage, to a critical metaphysician to question the abstract notions of existence in adolescence as in the metaphysical stage, and to a natural philosopher in adulthood as in the positive scientific stage. The Comte's parallel human-civilizational developments are broadened to include collectivism-individualism, human evolution, and developmental psychology from Erikson's psychosocial development, and are updated to include the stages after the nineteenth century. The four stages of infancy, toddlerhood, childhood, and adulthood in the proposed human development are parallel to the four stages of premodernity, modernity, postmodernity, and eu-modernity (post-postmodernity) in the proposed civilizational development. Each individual human develops from believing infancy to believe in parent as believing premodernity to believe in authoritative religion, to autonomous toddlerhood to explore as rational autonomous modernity to explore, to diverse childhood to learn diversity as diverse postmodernity to learn diversity, and to eusocial adulthood to establish eusociality by interdependent division of labor, multigenerational generativity, and intergroup generosity as eusocial eu-modernity to establish eusociality by interdependent division of labor between individualism and collectivism, multigenerational generativity for long-term wellbeing, and in-
\end{abstract}


tergroup generosity for long-distance wellbeing. Eusocial eu-modernity is the adulthood civilization.

\section{Keywords}

Premodernity, Modernity, Postmodernity, Eu-Modernity, Civilizational

Developmental Psychology, Human Developmental Psychology, Auguste

Comte, Erik Erikson, Eusociality, Parallel Developments

\section{Introduction}

In about 1822, Auguste Comte (1798-1857) known for founding sociology as a science attempted to discover the successive stages through which the European civilization had developed. He applied scientific methods of comparison and arrived at The Law of Human Progress or The Law of Three Stages consisting of the theological stage, the metaphysical stage, and the positive scientific stage (Comte \& Lenzer, 1998). In the theological stage, people believed that all phenomena are produced by the immediate action of supernatural beings. The theological stage was dominated by the priests and ruled by military men. In the metaphysical stage, people explained phenomenon by invoking abstract entities in terms of essences, ideals, and forms. The metaphysical stage which corresponded roughly to the Middle Ages and the Renaissance, was dominated by the Church men and lawyers. In the positive scientific stage, people establish scientific laws as the invariable relations of succession and resemblance and their links to observations. The positive scientific stage, which just started in the nineteenth century, would be dominated by industrial administrators and scientific moral guides.

Auguste Comte believed that civilizational development had taken place along with human development. In other words, he holds that each individual human develops from the stage of a devout believer in childhood as in the civilizational theological stage, to a critical metaphysician to question the abstract notions of existence in adolescence as in the civilizational metaphysical stage, to a natural philosopher in adulthood as in the civilizational positive scientific stage. As a result, Comte establishes the parallel between European civilizational development (the theological stage, the metaphysical stage, and the positive scientific stage) and human development (childhood, adolescence, and adulthood).

In this paper, the Auguste Comte's parallel human-civilizational developments in the early nineteen century are broadened and updated for the twenty-first century. The parallel human-civilizational developments are broadened to include the Eastern-Western civilizations for collectivism-individualism, human evolution, and developmental psychology from Erikson's psychosocial development (Erikson \& Erikson, 1998), and are updated to include the stages after the nineteenth century. In this paper, the proposed human developmental psychology has the four stages of infancy, toddlerhood, childhood, and adulthood, par- 
alleling to the four stages of premodernity, modernity, postmodernity, and postpostmodernity (eu-modernity), respectively, in the proposed civilizational developmental psychology.

The human development stages follow human developmental psychology. In developmental psychology (Hogan \& Vaccaro, 2006) to explain growth and change through the lifespan, the developmental stages of life are initiated by distinct transitions in physical, cognitive, and socioemotional developments. Different theories of developmental psychology have different stages of development. For examples, the Jean Piaget's four stages of cognitive development are sensorimotor stage, pre-operational stage, concrete operational stage, and formal operational stage (Wadsworth, 2004). A child must master each stage before moving to the next stage in a continuous learning process where each stage builds on the previous one. The Erik Erikson's eight stages of psychosocial (egosocial) development are infancy, toddlerhood, preschooler, schooler, adolescence, young adulthood, middle adulthood, and late adulthood (Erikson \& Erikson, 1998). Each stage is characterized by a basic psychosocial crisis, such as trust versus distrust and intimacy versus isolation. The acquisition of basic virtues, such as hope and love, results from successful completion of each stage. Basic virtues can be used by the ego to resolve subsequent crises.

This paper proposes identity development consisting of infancy, toddlerhood, childhood, and adulthood. Each stage has its principal identity, process of principal identity, attribute, and process of attribute. The identity development is derived from the Erikson's psychosocial development. The principal identity is basically the identity in the Erikson's crisis, and the principal attribute is basically the attribute in the Erikson's virtue. The attribute of each person is the accumulation of attributes.

The conventional stages of civilization consist of premodernity, modernity, postmodernity, and post-postmodernity. The founder of modernity is René Descartes (1596-1650). That "I think, therefore, I am" expresses both autonomy as "I" and rationality as "think". According to Anthony Giddens (1991) to describe autonomy, the most defining property of modernity is that we are disembedded from time and space. In premodernity, space was the area in which one moved and time was the experience one had while moving. In modernity, the social space is no longer confined by the boundaries set by the space in which one moves. Autonomy allows individuals to explore.

The motive force for autonomy is rationality originated from ancient Greece (Buxton, 1999). Original early rationality is the inner logic and consistency within a system, and is not science rationality which requires the test for its generalized propositions in observations (Zhang, 2013). This early rationality is equivalent to the Comte's consistent metaphysical abstraction which evolved into science rationality in the positive scientific stage. Modernity includes both the metaphysical stage and the positive scientific stage. People believe that under the guidance of rationality, they can free themselves from various natural and his- 
torical fetters, determine historical direction and aim relying on their own power, and shape their world and life freely (Honneth, 1987). As a result, premodernity represents the believing stage believing in authoritative religion, while modernity represents the rational autonomous stage to explore. Believing premodernity resembles believing infancy to believe in authoritative parent, and autonomous modernity resembles toddlerhood to walk autonomously for exploration.

During childhood, children meet other people outside of immediate family, resulting in diversity in experiences. Children learn diversity. Postmodernity derived from the Information Revolution for the rapid and global transmission of information is the time to encounter other cultures, resulting in diversity. Postmodernism rejects concepts of rationality, objectivity, and universal truth. Instead, it emphasizes the diversity of human experience and multiplicity of perspectives (Lyotard, 1984). As a result, diverse postmodernity resembles diverse childhood.

During adulthood, adults socialize by establishing relations in diversity. $\mathrm{Hu}-$ man sociality is evolved biologically as eusociality. Eusociality (eu in Greek means good) is the highest level of organization of sociality. Ants, bees, and termites are eusocial animals. Originally, eusociality was defined to include organisms (only invertebrates) that had the three features consisting of reproductive division of labor, overlapping generations, and cooperative care of young (Crespi \& Douglas, 1995). These three features can be generalized as interdependent division of labor, multigenerational generativity (Slater, 2003), and intergroup generosity. With this generalization, human is a eusocial species (Wilson, 2012) according to E.O. Wilson. The original human interdependent division of labor involved the interdependent division of labor between hunters and gatherers in the original human hunter-gatherer society, which is much earlier than Emile Durkheim's division of labor in the capitalist society (Durkheim, 1997). The human multigenerational generativity involves the women's long life after menopause to take care of their grandchildren. The human intergroup generosity involves human natural compassion.

Eusocial adulthood brings about eusocial eu-modernity. Eusocial adulthood to eusociality by interdependent division of labor, multigenerational generativity, and intergroup generosity corresponds to eusocial eu-modernity to eusociality by interdependent division of labor between individualism and collectivism, multigenerational generativity for long-term wellbeing, and intergroup generosity for long-distance wellbeing.

Human grows directionally in the body-mind domain through the interaction between genes and environments. Similarly, civilization develops (grows) directionally in the political-economic domain (band, tribe, nation, mega nation, global system, and interconnected world) through the interaction between technological revolutions (Upper Paleolithic, Agricultural-Pastoral, Bronze, Iron, Industrial, Information, and Intelligence revolutions) and societies. In human, each developmental stage with its specific size has its specific human psychological development. Similarly, in civilization, each developmental stage of with its specific 
size has its specific psychological development. This paper proposes the parallel identity developments between human identity development and civilizational identity development. Infancy, toddlerhood, childhood, and adulthood correspond to premodernity (band, tribe, and nation), modernity (mega nation), postmodernity (diverse culture), and eu-modernity (interconnected world), respectively.

The proposed human developmental psychology has the four stages of believing infancy, autonomous toddlerhood, diverse childhood, and eusocial adulthood, paralleling to the four stages of believing premodernity, rational autonomous modernity, diverse postmodernity, and eusocial eu-modernity, respectively, in the civilizational developmental psychology. Section 2, discusses the four stages of human identity development. Section 3 describes the four stages of civilizational identity development.

\section{The Four Stages of Human Identity Development}

Different theories of developmental psychology have different stages of development. For examples, The Jean Piaget's four stages of cognitive development are sensorimotor stage, pre-operational stage, concrete operational stage, and formal operational stage (Wadsworth, 2004) as in Table 1. A child must master each stage before moving to the next stage in a continuous learning process where each stage builds on the previous one.

The Erik Erikson's eight stages of psychosocial development are infancy, toddlerhood, preschooler, schooler, adolescence, young adulthood, middle adulthood, and late adulthood (Erikson \& Erikson, 1998) as in Table 2. According to

Table 1. The Piaget's cognitive development.

\begin{tabular}{|c|c|c|c|}
\hline age & stage & understands world through & learned cognitive capabilities \\
\hline $0-2$ & sensorimotor & senses and actions & $\begin{array}{l}\text { coordination of senses with motor responses and language used } \\
\text { for demands and cataloguing }\end{array}$ \\
\hline $2-7$ & preoperational & mental images and language & $\begin{array}{c}\text { symbolic thinking and language with proper syntax and grammar } \\
\text { to express full concepts }\end{array}$ \\
\hline $7-11$ & concrete operational & concrete rational thinking and categories & concepts attached to concrete situations \\
\hline $11+$ & formal operational & $\begin{array}{c}\text { abstract rational thinking and scientific } \\
\text { reasoning }\end{array}$ & $\begin{array}{l}\text { theoretical, hypothetical, and counterfactual thinking, abstract } \\
\qquad \text { logical reasoning }\end{array}$ \\
\hline
\end{tabular}

Table 2. The Erikson's psychosocial (ego-social) development.

\begin{tabular}{|c|c|c|c|c|c|c|c|c|}
\hline age & $0-1.5$ & $1.5-3$ & $3-5$ & $5-12$ & $12-18$ & $18-40$ & $40-65$ & $65+$ \\
\hline Stage \# & $1^{\text {st }}$ & $2^{\text {nd }}$ & $3^{\text {rd }}$ & $4^{\text {th }}$ & $5^{\text {th }}$ & $6^{\text {th }}$ & $7^{\text {th }}$ & $8^{\text {th }}$ \\
\hline stage & infancy & toddlerhood & $\begin{array}{l}\text { preschooler } \\
\text { age }\end{array}$ & schooler age & adolescence & $\begin{array}{c}\text { young } \\
\text { adulthood }\end{array}$ & $\begin{array}{c}\text { middle } \\
\text { adulthood }\end{array}$ & $\begin{array}{c}\text { late } \\
\text { adulthood }\end{array}$ \\
\hline ego crisis & $\begin{array}{l}\text { trust vs. } \\
\text { mistrust }\end{array}$ & $\begin{array}{c}\text { autonomy vs. } \\
\text { shame }\end{array}$ & $\begin{array}{l}\text { initiative vs. } \\
\text { guilt }\end{array}$ & $\begin{array}{l}\text { industry vs. } \\
\text { inferiority }\end{array}$ & $\begin{array}{c}\text { identity vs. role } \\
\text { confusion }\end{array}$ & $\begin{array}{c}\text { intimacy vs. } \\
\text { isolation }\end{array}$ & $\begin{array}{c}\text { generativity vs. } \\
\text { stagnation }\end{array}$ & $\begin{array}{c}\text { ego integrity vs. } \\
\text { despair }\end{array}$ \\
\hline $\begin{array}{l}\text { basic } \\
\text { virtue }\end{array}$ & hope & will & purpose & competency & fidelity & love & care & wisdom \\
\hline
\end{tabular}


the Erikson's psychosocial development, the ego develops through eight stages, each characterized by a basic psychosocial crisis, such as trust versus distrust and intimacy versus isolation. The acquisition of basic virtues, such as hope and love, results from successful completion of each stage. Basic virtues can be used by the ego to resolve subsequent crises.

This paper proposes identity development consisting of infancy, toddlerhood, childhood, and adulthood. Each stage has its principal identity, process of principal identity, attribute, and process of attribute. The identity development is derived from the Erikson's psychosocial development. The principal identity is basically the identity in the Erikson's crisis, and the principal attribute is basically the attribute in the Erikson's virtue. The attribute of each person is the accumulation of attributes. The four stages are infancy, toddlerhood, childhood, and adulthood where childhood is the combination of preschooler, schooler, and adolescence and adulthood is the combination of young, middle, and late adulthoods in the Erikson's psychosocial development as in Table 3.

\subsection{Infancy (From Birth to 1.5-Year 0ld)}

- Infancy starts at birth.

- The principal identity is parent or primary caregiver, and the process of parent-identity is parent-recognition.

- The broad identity of parent is territory.

- The crisis involving parent-identity is trust versus distrust parent, and the basic virtue is hope.

- The attribute of hope is belief, and the process is the belief in parent.

- A healthy infant is a believer.

- The major activity is the belief in parent.

Before birth, a fetus is basically a part of mother's body, so it does not need any identity. After birth, an infant needs parents or primary caregiver as identity to help the infant to survive. To walk well, human bipedalism limits the size of the pelvis, resulting in the narrow birth canal. Human brains become too big to pass through the birth canal when fully developed. A human newborn averages

Table 3. The four stages of human identity developmental psychology.

\begin{tabular}{|c|c|c|c|c|c|}
\hline stage & $\begin{array}{c}\text { Erikson } \\
\text { Stage, age }\end{array}$ & Identity/process & Erikson crisis/virtue & Attribute/process & Person \\
\hline infancy & $\begin{array}{c}1^{\text {st }} \\
0-1^{1 / 2}\end{array}$ & parents/parents-recognition & trust vs. mistrust/hope & belief/belief in parents & believer \\
\hline toddlerhood & $2^{2^{\text {nd }}}$ & self/self-recognition & autonomy vs. shame/will & autonomy/exploration & $\begin{array}{l}\text { autonomous } \\
\text { believer }\end{array}$ \\
\hline childhood & $\begin{array}{l}3^{\text {rd }}-5^{\text {th }} \\
3-18\end{array}$ & $\begin{array}{l}\text { other people/theory of mind } \\
\text { to learn diverse perspectives }\end{array}$ & $\begin{array}{l}\text { initiative vs. guilt/purpose, industry vs. } \\
\text { inferiority/competency, identity vs. } \\
\text { role confusion/fidelity }\end{array}$ & diversity/learning & $\begin{array}{l}\text { diverse } \\
\text { autonomous } \\
\text { believer }\end{array}$ \\
\hline adulthood & $\begin{array}{l}6^{\text {th }}-8^{\text {th }} \\
18-65+\end{array}$ & $\begin{array}{l}\text { society/sociality to establish } \\
\text { relations in diversity }\end{array}$ & $\begin{array}{c}\text { intimacy vs. isolation/love, generativity } \\
\text { vs. stagnation/care, ego integrity vs. } \\
\text { despair/wisdom }\end{array}$ & $\begin{array}{l}\text { eusociality/interdependent } \\
\text { division of labor, } \\
\text { generativity, generosity }\end{array}$ & $\begin{array}{l}\text { eusocial diverse } \\
\text { autonomous } \\
\text { believer }\end{array}$ \\
\hline
\end{tabular}


$369 \mathrm{ml}$, and increases, during the first year of life, to about $961 \mathrm{ml}$, after which the growth rate declines. Brain volume peaks at the age of 40 after which it begins declining at 5\% per decade, speeding up around 70 (Peters, 2006). Adult Homo sapiens have brains averaging $1200 \mathrm{ml}$ or more. Consequently, human infants are highly immature, unlike other great apes that have precocial newborns with the relatively mature brains. A newborn's brain has a well-developed brainstem and midbrain to carry out the bodily functions necessary for life, but the sections of the brain that are involved in regulating emotions and motions and learning language grow and develop after birth, so human newborns remain physically altricial for a very long time.

Altricial infant needs parent. The principal identity in infancy is parent. The process for the parent identity is parent-recognition. An infant feels more comfortable around the mother because not only is the mother's scent and voice familiar, but the infant also sees more of her all through the day, which is why infants recognize their mothers first. By the time infants turns three months old and can distinguish between various faces, the infant may become wary of strangers and unknown faces, and may start to cry to get attention from their parents.

Territory-recognition is developed at the same time as parent-recognition. Infants have territorial instinct with the family boundary between ingroup and outgroup. Infants basically live in ingroup where individuals have similar interests and outlooks, and produce the feeling of cooperation among people in ingroup (Turner \& Reynolds, 2010). The worldview for infants is territorial worldview against people in outgroup with the feeling of zero-sum competition. As shown in the Infant Cognition Center at Yale University, infants at few months old (Hamlin, Mahajan, \& Wynn, 2013) prefer the objects (such as dolls) as ingroup objects that have similarities with the babies rather than the objects as outgroup objects that do not have similarities with the babies. Babies also prefer the objects with helpful behavior to the objects with bully behavior. However, babies prefer the doll that bullies another doll that is not like the babies. In other words, even though babies dislike the individuals who harm other individuals, babies prefer the individuals who harm outgroup individuals that are not like the babies. Territory can be considered as broad parent, while territory-recognition can be considered as broad parent-recognition.

Parent identity leads the crisis of trust vs. distrust parent in the Erikson's development. During infancy, experiencing unhealthy stress when young can cause the child to develop a low stress threshold and become overly reactive to adverse experiences throughout life. The infants without proper care suffer lifelong fear and hopelessness anywhere. The infants with proper care generate the virtue of hope. The attribute of hope is belief, and the process of belief is the belief in parent. A healthy infant is a believer in parent. The major activity is the belief in parent.

\subsection{Toddlerhood (1.5 - 3)}

- Toddlerhood starts at walking. 
- The principal identity is self, and the process is self-recognition.

- The principal attribute is autonomy, and the process is exploration.

- A toddler is an autonomous believer.

- The Erikson's crisis is autonomy vs. shame.

- The Erikson's virtue is the will to live in ingroup.

- The major activity is autonomous exploration.

Toddlerhood starts at walking without the help of parent. The principal identity is self, and the process of self-identity is self-recognition. In a typical test for self-recognition, a toddler who has a red dot on the forehead touches the red dot when the toddler looks in the mirror. An infant does not have self-recognition, while a toddler at the age of about 18 months has self-recognition. Most animals, such as dogs, cats, and monkeys do not have self-recognition.

The self-identity leads to the crisis of autonomy vs. shame in the Erikson's development. Sufficient learned skills and learned traditions allow a toddler to have autonomy. Insufficient learned skills and learned traditions cause a toddler to have doubt/shame. The Erikson's virtue for lifelong capability is the will to live. The attribute of will is autonomy. The process for autonomy is exploration to learn various skills and traditions. A healthy toddler is an autonomous believer. The major activity is autonomous exploration.

\subsection{Childhood (3 - 18)}

- Childhood starts at weaning.

- Childhood is the combination of preschooler (pre-juvenile), schooler, and adolescence in the Erikson's psychosocial development.

- The principal identity is other people, and the process is theory of mind to learn diverse perspectives.

- The Erikson's crises/virtues are Initiative vs. guilt/purpose, industry vs. inferiority/competency, identity vs. role confusion/fidelity.

- The attribute for the virtues is diversity, and the process is learning.

- A healthy child is a diverse autonomous believer.

- The major activity is the learning of diversity.

Childhood starts at weaning at the age of about 3 for the human archaeological population whose weaning was about two to three years earlier than other great apes (Tsutaya \& Yoneda, 2013). The earlier weaning allowed higher numbers of childbirths which made Homo sapiens more successful than other great apes in terms of population (Bogin \& Varea, 2016). The early weaning also makes pre-juvenile age ( 3 to 5 ) difficult period without sufficient maturity and the full maternal care that diverts to a newborn sibling. Other great apes whose weaning occurs at the age of five or six do not have this difficult pre-juvenile age.

Such early weaning is possible for humans because of theory of mind. Developmental psychologists define the theory of mind as the ability to take another person's viewpoint, and attribute mental state of mind to the others. No other animals have such robust theory of mind. Theory of mind was evolved originally 
to accommodate interdependent division of labor between the forest specialist group (women and children) and the woodland specialist group (men) in early hominins who lived the mixed forest-woodland habitat (Chung, 2016a). To complement each other's work without interfering each other's work, one specialist group had to recognize that the other specialist group existed to think for themselves and to do different works. The result was theory of mind which is to recognize that the others exist to think for themselves. (The forest-woodland groups became the hunter-gatherer groups for the Homo species in the savanna habitat.)

A typical test for theory of mind is the Sally-Anne test (Baron-Cohen, Leslie, \& Frith, 1985). In a short video skit which is shown a child under the test, Sally takes a marble and hides it in a red box. She then "leaves" the room. While she is away, Anne takes the marble out of the red box, and puts it in a blue box. Sally comes back to the room, and the child is asked the key question, "Where will Sally look for her marble?" The answer of children without theory of mind is blue box, while the answer of children with theory of mind is red box, and they realize that different people can have different viewpoints.

According to Jean Piaget, pre-juveniles start to use the language with proper syntax and gramma to express full concept. The language with proper syntax and gramma provides the necessary tool to describe, think, and express precisely and accurately complex occurrences such as false beliefs. With the ability to describe, think, and express in the language with proper syntax and gramma, prejuveniles start to have explicit theory of mind for complex occurrences. Without the language of proper syntax and gramma, human toddlers and other great apes have only implicit theory of mind which gets confused easily and explicitly about complex occurrences such as false beliefs (Krupenye et al., 2016). Explicit theory of mind allows pre-juveniles to understand other people's attitudes and specialties and to coordinate with them. After weaning, pre-juveniles still highly depend on older individuals for food and protection until about age 6 or 7 years old. Through explicit theory of mind, pre-juveniles find and coordinate with right older individuals with right attitudes and specialties to help them. As a result, with explicit theory of mind, pre-juveniles without full maternal care could survive after weaning in the hunter-gatherer society during the human evolution, while other great apes without explicit theory of mind needed full maternal care until the age of five or six.

Wellman and Liu (Wellman \& Liu, 2004) developed a battery of five tasks measuring the developmental sequence of theory of mind. From the easiest to the most difficult, the five tasks are: 1) Diverse Desires: the child judges that the self and another have different desires about the same object; 2) Diverse Beliefs: the child judges that the self and another have different beliefs about the same object, when the veracity of the belief is unknown to the child; 3) Knowledge Access: the child sees what is in a box and judges the knowledge of another who has not seen the contents of the box; 4) Contents False Belief: the child judges 
another's false belief about what is in a distinctive container when the child knows what is in the container; 5) Hidden Emotion: the child judges that a person can have one emotion internally but can display a different emotion externally. In summary, theory of mind is basically about diverse perspective. As a result, for childhood, the principal identity is other people, and the process for the identity of other people is theory of mind to learn diverse perspective.

In the identity development, childhood is the combination of preschooler (pre-juvenile), schooler, and adolescence in the Erikson's psychosocial development. The identity of other people leads to the Erikson's crises/virtues including initiative vs. guilt/purpose for pre-juvenile age (preschooler), industry vs. inferiority/competency for juvenile age (schooler), identity vs. role confusion/fidelity for adolescence. Pre-juvenile (preschooler) take initiative to understand diversity from other people. If such initiative is restricted, pre-juvenile feel guilty about dealing with diversity. With initiative to deal with diversity, the world is open with purpose. Juvenile (schooler) goes to school to learn about diversity. If children are encouraged and reinforced for their initiative, they are industrious to make them competent. If this initiative is restricted by parents or teacher, then the children feel inferior, doubting his own abilities and therefore may not reach his or her potential. Adolescents with enough exposure to diversity find their identities; otherwise, they feel confused about their identities. In general, the attribute of the Erikson's virtues (purpose, competency, and fidelity) is diversity, and the process of the attribute is learning. A healthy child is a diverse autonomous believer. The major activity is the learning of diversity.

\subsection{Adulthood (18 - 65+)}

- Adulthood starts at higher learning-first childbirth.

- Adulthood is the combination of young, middle, and late adulthoods in the Erikson's psychosocial development.

- The principal identity is society, and the process for society-identity is sociality to establish relations in diversity.

- The Erikson's crises/virtues include intimacy vs. isolation/love, generativity vs. stagnation/care, and ego integrity vs. despair/wisdom

- The attribute of love, care, and wisdom is eusociality, and the process of eusociality consists of interdependent division of labor, generativity, and generosity.

- A healthy adult is a eusocial diverse autonomous believer.

- The major activity is eusociality.

Normally, an adult starts to pursuit higher learning such as college education and career at the age of 18 . In the hunter-gatherer society, the average age for the first childbirth is 19 . Young adults in twenties until mid to late 30 s are at the peak of physiological development including reproductive system, motor ability, strength, and lung capacity. After mid to late 30s, these systems start a slow and gradual decline to show signs of aging. 
Basically, adulthood starts from the entrance into society and the beginning of serious social responsibility. The childhood's playfulness and affectation about diversity cannot deal with real social relations, social problems, and social responsibility. It is necessary to find real relations in diverse perspectives in the highly connected diverse society. The end of diverse childhood leads to the start of social adulthood. The principal identity in adulthood is society, and the process for the society-identity is sociality to establish relations in diversity. Sociality involves the mature social brain (Chung, 2018). During the adulthood, the connection among neurons in the brain becomes more efficient and numerous than in the childhood brain. As a result, the adult mature brain is equipped to find real relations in diverse perspectives in the highly connected diverse society.

Human sociality is evolved biologically as eusociality. Eusociality (eu in Greek means good) is the highest level of organization of sociality. Ants, bees, and termites are eusocial animals. Originally, eusociality was defined to include organisms (only invertebrates) that had the three features consisting of reproductive division of labor, overlapping generations, and cooperative care of young (Crespi \& Douglas, 1995). These three features can be generalized as interdependent division of labor, multigenerational generativity (Slater, 2003), and intergroup generosity. With this generalization, human is a species of eusocial ape (Wilson, 2012) according to E.O. Wilson. The original human interdependent division of labor involved the interdependent division of labor between hunters and gatherers in the original human hunter-gatherer society, which is much earlier than Emile Durkheim's division of labor in the capitalist society (Durkheim, 1997). The human multigenerational generativity involves the women's long life after menopause to take care of their grandchildren. The human intergroup generosity involves human natural compassion.

In the identity development, adulthood is the combination of young, middle, and late adulthoods in the Erikson's psychosocial development. The identity of society leads to the crises and virtues in the Erikson's psychosocial development. In young adulthood (18 - 40), the crisis is intimacy vs. isolation, and the basic virtue is love. During this stage, young adults begin to share themselves more intimately with others. They explore relationships leading toward longer-term commitments with someone other than a family member. Successful completion of this stage can result in happy relationships and a sense of commitment, safety, and care within a relationship. Avoiding intimacy, fearing commitment and relationships can lead to isolation, loneliness, and sometimes depression. Success in this stage will lead to the virtue of love. For humans as eusocial ape, such love involves interdependent division of labor between men as hunters and women as gatherers (Chung, 2016a). Interdependent division of labor is extended to other tasks.

In middle adulthood (40 - 65), the crisis is generativity versus stagnation, and the basic virtue is care. Generativity that exists only in eusocial humans involves the care and concern from older people to establish and guide future generations 
(Slater, 2003) as the legacy to the whole society (McAdams \& De St. Aubin, 1992). In the monogamous hunter-gatherer society during human evolution, individuals (monogamous couples) after menopause became infertile. Such infertile individuals at the age of menopause were likely to be leaders-mentors with abundant knowledge, experiences, and social connections, even though physically they were weaker than young adults. After menopause, these infertile leadersmentors could not have dependent children, so without dependent children, the infertile leaders-mentors were generous in protecting next generation instead of protecting their own dependent children. At the same time, without the physical strength of young adults, infertile leaders-mentors needed the physical protection from strong young adults who did not have comparable generosity in the protection of next generation as well as comparable knowledges, experiences, and social connections as infertile leaders-mentors. As a result, in the human division of labor for interdependent sociality, infertile leader-mentor became an interdependent specialist. The generous, knowledgeable, experienced, and wellconnected infertile leader-mentor specialists provided a significant evolutionary competitive advantage in the human evolution, resulting in long life after menopause unlike other great apes that have short life after menopause. Increased longevity through generativity was proved by the computer simulation of increased longevity through grand-mothering (Kim, Coxworth, \& Hawkes, 2012). During the human evolution, some unique variants, such as ApoE3, in genes were evolved to lower the risk of most aging diseases (Finch \& Stanford, 2004).

During middle adulthood, through generality, individuals create and nurture things that will outlast them, and benefit all social groups. Middle adulthood provides generativity for multigenerational care and generosity for intergroup care which are parts of eusociality. Success in interdependent care leads to feelings of usefulness and accomplishment to the virtue of care. The failure to find a way to contribute leads to stagnation.

In late adulthood (65+), the crisis is ego integrity versus despair, and the basic virtue is wisdom. This stage begins at approximately age 65 and ends at death. It is during this time that we contemplate our accomplishments and can develop integrity if we see ourselves as leading a successful life. Individuals who reflect on their life and regret not achieving their goals will experience feelings of bitterness and despair. Success in this stage will lead to the virtue of wisdom.

The attribute for the Erikson's virtues of love, care, and wisdom is eusociality, and the process of eusociality consists of interdependent division of labor, generativity, and generosity. A healthy adult is a eusocial diverse autonomous believer. The major activity in adulthood is eusociality.

\section{The Four Stages of Civilizational Identity Development}

In the previous section, the four stages of human identity development are be- 
lieving infancy, autonomous toddlerhood, diverse childhood, and eusocial adulthood. In this section, the four stages of human identity development as believing infancy, autonomous toddlerhood, diverse childhood, and eusocial adulthood correspond to the four stages of civilization identity development as believing premodernity, autonomous rational modernity, diverse postmodernity, and eusocial eu-modernity, respectively as in Table 4 . The civilizational identity development involves politics, production types (Chung, 2020b), and religions as in Table 5. In human identity development, the growth in body-mind domain is through the interaction between genes and environments. In civilizational identity development, the growth in political-economical domain is through the interaction between technological revolutions and societies.

\subsection{Premodernity (from the Upper Paleolithic Period to the Iron Age)}

- Premodernity starts from the Upper Paleolithic Technological Revolution.

- The other revolutions in Premodernity include the Agricultural-Pastoral Revolution and the Bronze Revolution.

- Premodernity corresponds to believing infancy.

- The principal identity is imaginary guardian, and the process for the identity of imaginary guardian is theory of imaginary mind.

- The principal attribute is belief, and the process is the belief in imaginary guardian.

- The political systems include hunter-gatherer band, pastoral-agricultural tribes, and individualistic-collectivistic nations.

- The religious systems include animism, afterlife, shamanism, high gods and ancestor worship, and polytheism

- Premodernity is believing civilization.

- The major activity is the belief in imaginary guardian.

Premodernity consists of linked hunter-gatherer band, split agrarian-pastor tribes, and split collective-individualistic nations.

Table 4. The four-stages of civilizational identity development.

\begin{tabular}{|c|c|c|c|c|c|}
\hline Civilization & Human & Technological Revolution & Identity/process & Attribute/process & Civilization \\
\hline premodernity & $\begin{array}{l}\text { believing } \\
\text { infancy }\end{array}$ & $\begin{array}{c}\text { Upper Paleolithic } \\
\text { /Agricultural-Pastoral/ } \\
\text { Bronze }\end{array}$ & $\begin{array}{l}\text { imaginary guardian/theory of } \\
\text { imaginary mind }\end{array}$ & $\begin{array}{l}\text { belief/belief in imaginary } \\
\text { guardian }\end{array}$ & believing civilization \\
\hline Modernity & $\begin{array}{l}\text { autonomous } \\
\text { toddlerhood }\end{array}$ & Iron/Industrial & human mind/rationality & $\begin{array}{l}\text { rational autonomy/ } \\
\text { exploration }\end{array}$ & $\begin{array}{l}\text { autonomous rational } \\
\text { believing civilization }\end{array}$ \\
\hline postmodernity & $\begin{array}{l}\text { diverse } \\
\text { childhood }\end{array}$ & Information & $\begin{array}{l}\text { other cultures/theory of mind } \\
\text { to learn diverse cultures }\end{array}$ & diversity/learning & $\begin{array}{c}\text { diverse autonomous } \\
\text { rational believing } \\
\text { civilization }\end{array}$ \\
\hline eu-modernity & $\begin{array}{c}\text { eusocial } \\
\text { adulthood }\end{array}$ & Intelligence & $\begin{array}{l}\text { interconnected } \\
\text { world/Internationalization to } \\
\text { establish relations in diversity }\end{array}$ & $\begin{array}{l}\text { eusociality/interdependent } \\
\text { division of labor, } \\
\text { multigenerational generativity, } \\
\text { intergroup generosity }\end{array}$ & $\begin{array}{l}\text { eusocial diverse } \\
\text { autonomous rational } \\
\text { believing civilization }\end{array}$ \\
\hline
\end{tabular}


Table 5. The four stages of civilizational identity development in politics, production type, and religion.

\begin{tabular}{|c|c|c|c|c|c|c|}
\hline $\begin{array}{l}\text { Stage/identity/ } \\
\text { attribute }\end{array}$ & Political Entity & $\begin{array}{l}\text { Technological } \\
\text { revolution }\end{array}$ & $\begin{array}{l}\text { Worldview/ } \\
\text { boundary }\end{array}$ & Source of politics & $\begin{array}{l}\text { Production } \\
\text { Type }\end{array}$ & Religion \\
\hline \multirow{5}{*}{$\begin{array}{l}\text { Premodernity/ } \\
\text { imaginary } \\
\text { guardian/ } \\
\text { belief }\end{array}$} & $\begin{array}{c}\text { interdependent linked } \\
\text { hunter-gatherer } \\
\text { band }\end{array}$ & $\begin{array}{c}\text { Upper } \\
\text { Paleolithic }\end{array}$ & $\begin{array}{l}\text { egalitarian } \\
\text { territorialism/ } \\
\text { rigid }\end{array}$ & belief & $\begin{array}{l}\text { interdependent } \\
\text { adventurous- } \\
\text { consolidative }\end{array}$ & $\begin{array}{l}\text { animism, } \\
\text { afterlife, } \\
\text { shamanism }\end{array}$ \\
\hline & $\begin{array}{c}\text { individualistic nomadic } \\
\text { pastoral-trade tribe }\end{array}$ & Pastoral & $\begin{array}{l}\text { individualistic } \\
\text { territorialism/ } \\
\text { rigid }\end{array}$ & belief & adventurous & $\begin{array}{l}\text { high gods and } \\
\text { ancestor } \\
\text { worship }\end{array}$ \\
\hline & $\begin{array}{l}\text { collectivistic settled } \\
\text { agrarian } \\
\text { tribe }\end{array}$ & Agricultural & $\begin{array}{l}\text { collectivistic } \\
\text { territorialism/ } \\
\text { rigid }\end{array}$ & belief & consolidative & $\begin{array}{l}\text { high gods and } \\
\text { ancestor } \\
\text { worship }\end{array}$ \\
\hline & $\begin{array}{l}\text { individualistic feudal } \\
\text { nation }\end{array}$ & Bronze & $\begin{array}{l}\text { individualism/ } \\
\text { flexible }\end{array}$ & belief & adventurous & polytheism \\
\hline & $\begin{array}{c}\text { collectivistic authoritarian } \\
\text { nation }\end{array}$ & Bronze & $\begin{array}{l}\text { collectivism/ } \\
\text { flexible }\end{array}$ & belief & consolidative & polytheism \\
\hline \multirow{4}{*}{$\begin{array}{l}\text { Modernity/ } \\
\text { human mind/ } \\
\text { autonomous } \\
\text { rationality }\end{array}$} & $\begin{array}{l}\text { individualistic capitalist } \\
\text { mega nation }\end{array}$ & Iron & $\begin{array}{l}\text { individualism/ } \\
\text { flexible }\end{array}$ & $\begin{array}{c}\text { belief }+ \text { rule of law }+ \\
\text { liberty }\end{array}$ & adventurous & monotheism \\
\hline & $\begin{array}{l}\text { collectivistic meritocratic } \\
\text { mega nation }\end{array}$ & Iron & $\begin{array}{l}\text { collectivism/ } \\
\text { flexible }\end{array}$ & $\begin{array}{c}\text { belief }+ \text { rule of relation }+ \\
\text { division of professional }\end{array}$ & consolidative & henotheism \\
\hline & $\begin{array}{l}\text { individualistic liberty } \\
\text { democracy }\end{array}$ & Industrial & $\begin{array}{l}\text { individualism/ } \\
\text { flexible }\end{array}$ & $\begin{array}{c}\text { belief }+ \text { rule of law }+ \\
\text { liberty }+ \text { affluence }\end{array}$ & adventurous & $\begin{array}{l}\text { monotheism, } \\
\text { religious } \\
\text { tolerance }\end{array}$ \\
\hline & $\begin{array}{l}\text { collectivistic common } \\
\text { professional democracy }\end{array}$ & Industrial & $\begin{array}{l}\text { collectivism/ } \\
\text { flexible }\end{array}$ & $\begin{array}{c}\text { belief }+ \text { rule of relation }+ \\
\text { division of professional }+ \\
\text { affluence }\end{array}$ & consolidative & henotheism \\
\hline $\begin{array}{l}\text { Postmodernity/ } \\
\text { other cultures/ } \\
\text { diversity }\end{array}$ & $\begin{array}{l}\text { collectivistic democratic } \\
\text { pluralism }\end{array}$ & information & $\begin{array}{l}\text { collectivism/ } \\
\text { flexible }\end{array}$ & $\begin{array}{c}\text { belief }+ \text { rule of relation }+ \\
\text { division of professional }+ \\
\text { affluence }+ \text { diversity }\end{array}$ & consolidative & $\begin{array}{l}\text { collectivistic } \\
\text { religious } \\
\text { pluralism }\end{array}$ \\
\hline $\begin{array}{l}\text { Eu-modernity/ } \\
\text { interconnected } \\
\text { world/ } \\
\text { eusociality }\end{array}$ & $\begin{array}{l}\text { interdependent } \\
\text { democracy }\end{array}$ & Intelligence & $\begin{array}{l}\text { interdependent } \\
\text { individualism- } \\
\text { collectivism/ } \\
\text { flexible }\end{array}$ & $\begin{array}{c}\text { belief }+ \text { rules of relation-law }+ \\
\text { liberty-division-of-professional } \\
+ \text { affluence }+ \text { diversity }+ \\
\text { eusociality }\end{array}$ & $\begin{array}{l}\text { interdependent } \\
\text { adventurous- } \\
\text { consolidative }\end{array}$ & $\begin{array}{l}\text { eusocial } \\
\text { religions }\end{array}$ \\
\hline
\end{tabular}

\subsubsection{Linked Hunter-Gatherer Band}

Before the birth of premodernity in the Upper Paleolithic Period starting about 40,000 years ago, the society was pre-premodernity corresponding to fetus in the human identity development. Fetus has no principal identity, because a fetus is a part of her or his mother's body. In the same way, pre-premodernity is a part of human biological evolution. Everything was instinctive directly evolved from human biological evolution without extra identity such as imaginary guardian. Pre-premodernity started from 200,000 years ago as the original hunter-gatherer band. Before pre-premodernity, bipedal human ancestors evolved about 6 million years ago (Chung, 2016a). Around 6 millions of years ago, a major climate change reduced some part of forested area in Africa to woodland where Ardi 
(Ardipithecus ramidus) (White et al. 2009) was evolved. Ardi, the oldest human ancestor (4.4 million year old) discovered, lived on woodland. Similar to other apes, Ardi's skull encased a small brain-300 to $350 \mathrm{cc}$. She lived in the mixed habitat of grassy woodland with patches of denser forest, and freshwater springs. The appearance of woodland caused the evolution from the human-chimpanzee-bonobo common ancestor to produce the bipedal human ancestors, the early hominins. Woodland allowed increasingly amount of food from bushes and low branches, which could be seen and reached from the ground. According to the observation (Carvalho et al. 2012) in Africa, chimpanzees today move on two legs most often when feeding on the ground from bushes and low branches. When food resources are scarce or unpredictable, chimpanzees use upright locomotion to improve food carrying efficiency. It suggests that the same might have occurred among the early hominins.

For reaching food from low branches on woodland and to carry food, the early hominins came down to the ground partly (not entirely) from living among trees, and adopted bipedalism as the way to move on the ground. However, Ardi's foot was primitive with an opposable big toe that could not provide a push needed for efficient bipedal walking. Ardi had a more primitive walking ability than later hominins, and Ardi had a somewhat awkward gait when on the ground. Its feet were still adapted for grasping trees rather than walking for long distances and running fast on the ground. (For apes, the quadrupedal knuckle-walking like gorillas, bonobos, and chimpanzees was faster and better way than Ardi's primitive awkward bipedalism to move on the ground.) The movement handicap of bipedalism on the ground was serious for very young, very old, and pregnant early hominins. To the early hominins in the mixed habitats, the area with many tall trees was the safe home area where very young, very old, and pregnant hominins stayed, and where they could escape quickly to the safety in tall trees, and the area with few tall trees was the unsafe exploration area for the exploration to find extra foods that could not be found in the safe home area. The two free hands from bipedalism allowed the early hominins to carry a large quantity of food home from the exploration as proposed by C. Owen Lovejoy (Lovejoy, 2009) and to carry simple defensive weapons such as sticks and stones to defense against large predators in the unsafe area. The exploration also allowed them to scavenge meats left by carnivores.

Consequently, the bipedalism and the mixed habitat divided the early hominins into the interdependent specialists which were the homemaker-forager who took care of children and foraged in the safe home forest area and the adventurist-forager who explored and foraged in the unsafe exploration woodland area. A good homemaker-forager was able to do multitask and navigate through landmarks (different trees) as women today. A good explorer-forager was able to have a good sense of direction (orientation in space) for exploration and strong upper body strength to carry foods and defensive weapons as men today. The homemaker-forager included both fertile homemaker-forager and infertile ho- 
memaker-forager. Women today become infertile after menopause at about the age of 51. A today woman's best reproductive years are in her 20s. Fertility gradually declines in the 30s, particularly after age 35 . The division of labor allowed the early hominins to take full advantage of the mixed habitat in terms of security and food procurement.

Such interdependent specialists group for interdependent division of labor produced theory of mind (mind-reading) that recognizes that the others exist to think for themselves. Theory of mind is derived from theory of specialty (specialty-reading) in interdependent specialists group where each specialist has its own specialty of work and work plan. In theory of specialist, each specialist must recognize that each specialist has its own specialty different from the specialties of other specialists, and each specialist has its own work plan distinctively different from the work plans of other specialists. To work together interdependently, all specialists must have theory of specialist in order to avoid overlapping unproductively and dangerously each other's work. Theory of specialty turned into theory of mind where specialty was replaced by the mind of each person. In theory of generality, each generalist does not need to distinctively recognize the types of work and work plans of other generalists, because they are not distinctively different. Interdependence required gentle temperament toward one another for interdependent relationship. Gentle temperament was shown in the disappearance of sharp canine teeth in early human ancestors as the only apes without sharp canine teeth for internal fighting.

The further gradual drying turned the mixed forest-woodland habitat into the mixed woodland-savanna habitat. Early Homos, such as Homo habilis and Homo naledi, lived in the mixed woodland-savanna habitat. They were good at tree-climbing and bipedal walking, and could run better than early hominins. Upon further drying, Middle Homos, such as Homo erectus, lived in savanna habitat originally. Without the foods from woodland, they had division of labor with the gatherer group to gather plant foods and the hunter group to hunt animals for meat. They were good at bipedal walking and running, but not tree climbing. The production type (Chung, 2020b) for hunters is adventurous production type which is high risk and high nutrition (high-profit) to hunt unpredictable and dangerous food targets, while the production type for gatherers is consolidative production type which is low risk and low nutrition (low-profit) to collect predictable and safe food targets. In the interdependent division of labor, hunters and gatherers understand each other through theory of mind, and share foods together. Homo erectus had medium size brains. The brain size increase was due to the intake of nutritious meat to supply energy and fat for the expanding energy-fat hungry brain. The period between 800,000 and 200,000 years ago is the period of strongest climate fluctuation worldwide, resulting in adverse habitat that endangered the existence of Homos. To increase reproductive success under such evolutionary pressure, the brain size increased. The result was the emergency of late Homos, such as Homo sapiens and Neanderthals. 
A band society of original hunter-gatherers was the simplest form of human society. Their power structure is egalitarian. A band generally consists of a small group ranging from 30 to 50 people (Zatrev, 2014). The human social brain can instinctively manage the social group size of about 150 people (Dunbar's Number) (Dunbar, 1992), so before the linked band stage, people in a band from 30 to 50 people could instinctively deal with several bands at the same time. There was no evidence for extensive religious practice (Wunn, 2000), so from about 200,000 to about 40,000 years ago, humans were irreligious, basically, because there was no need for religion.

Religions became significant during the Upper Paleolithic Period. During the Upper Paleolithic Period, a number of sudden temperature drops reduced significantly the area for forest in Europe and Asia. The Neanderthal became extinct during this period. The reduction of forest reduced the food supply, usable timber, and other non-food materials. The reduction of the number of trees forced humans to look for alternatives to wood to make tools. The new tools used bone, antler, and ivory. During this time, humans also learned to apply heat to clay objects in order to harden them. Humans also made advanced tools including fish hooks, rope, oil lamps, and eyed needles. The invention of complex tool led to the Upper Paleolithic Revolution in the Upper Paleolithic Period between 10,000 and 40,000 years ago before the Agricultural Revolution. Similar to the Industrial and Agricultural Revolutions, the Upper Paleolithic Revolution during the Upper Paleolithic period represents a short time span when numerous inventions appeared and cultural changes occurred (Bar-Yosef, 2002).

The invention of complex tools required a large network of production and trade. The interaction among many bands in this large network of production and trade was reinforced by the new religions. During the Upper Paleolithic Period, the new religions of female figurines (Dixson \& Dixson, 2011) and cave paintings (Lewis-Williams, 2002) were developed. The enormous distribution of these female figurines implied a ritualistic exchange system with the figurines playing a central role in intergroup relations (Cunliffe, 2001). The new religions that reinforced the interaction among bands allowed people to deal with the population much more than 150 people (Dunbar's Number). The Upper Paleolithic Revolution resulted in the linked band stage.

Religion became necessary and permanent part of stable linked band social structure. Without religion (Wunn, 2000), the Neanderthal became extinct during this period. The religions in the linked band stage included animism, afterlife, and shamanism. Female figurines and cave paintings are animism. Peoples, Duda, and Marlowe found the oldest trait of religion, present in the most recent common ancestor of present-day hunter-gatherers, was animism. Belief in an afterlife emerged, followed by shamanism. Ancestor worship and high gods who are active after the Upper Paleolithic Period were absent in early hunter-gatherer, suggesting a deep history for the egalitarian nature of hunter-gatherer societies (Peoples, Duda, \& Marlowe, 2016). 
Religions involve imaginary guardians. The principal identity for premodernity is imaginary guardian. The process for imaginary guardian is theory of imaginary mind where a person attribute mental states of mind (beliefs, intents, desires, emotions, knowledge, etc.) to imaginary guardians, and understand that imaginary guardians have beliefs, desires, intentions, and perspectives that are different from the person (Chung, 2016b, 2019). Theory of imaginary mind is derived from theory of real mind as the original theory of mind a person attribute mental state of mind to the others as real people, not imaginary entities. Humans under existential pressure invented theory of imaginary mind for imaginary specialists as imaginary agents who existed to think for themselves and to do different work in imaginary division of labor to enhance survival chance, resulting in the religious relief of stress and anxiety to enhance the survival chance of individuals. Under existential pressure, such theistic imagination can also be the religious enforcement of social bonds to enhance the survival chance of social group (Norenzayan et al., 2016; Shilling \& Mellor, 1998). Robust religion is unique to humans, because robust theory of mind is unique to humans (Heyes, 2015). According to Maurice Bloch (Bloch, 2006), the first widespread human religion was derived from the imagination to produce imaginary female figurines and imaginary cave paintings to helps them to survive under existential pressure at the time of the Upper Paleolithic Revolution.

According to a PET study, theory of mind activates the medial prefrontal node to handle the mental state of the self, the superior temporal sulcus to detect the behavior of other animals and analyzes the goals and outcomes of this behavior, and the inferior frontal region to maintain representations of actions and goals (Calarge, Andreasen, \& O'Leary, 2003). According to Kapogiannis and Deshpande in the functional MRI study of the brains of both self-declared religious and non-religious individuals, individuals with stronger theory of mind activity were found to be more religious (Kapogiannis et al., 2014). Thinking about God activates brain regions associated with theory of mind (Kapogiannis et al., 2009). Autistic individuals with problems in imaginative capacities and pretend plays are incapable of theory of mind (Scott \& Baron-Cohen, 1996; Angus et al., 2015; Chan et al., 2016). Autism with the deficits in theory of mind is linked to lower belief in God (Norenzayan, Gervais, \& Trzesniewski, 2012).

Up to two-thirds of the children who have the ability for theory of mind between the ages of 3 and 8 have imaginary companions (Taylor, 1999). They need imaginary companions to provide comfort in times of stress, boredom, and loneliness, to help them make sense of the adult world, and to overcome traumatic experiences. Taylor feel imaginary companions are common among children and are part of normal social-cognitive development (Taylor et al., 2004). For adults, such childhood imaginary companions are replaced by adulthood imaginary guardians. As a result, to believers, such imaginary guardians become real supernatural guardians to maintain cohesive large social group and to uphold believers' mental health. Large social groups and believers cannot survive well without adulthood imaginary guardians which will be discussed further in Sec- 
tion 3.4.2.5. The attribute of premodernity is belief, and the process for belief is the belief in imaginary guardian.

\subsubsection{Split Agrarian-Pastoral Tribes}

The agrarian-pastoral technological revolution split the hunter-gatherer bands into settled agrarian tribes on fertile agrarian land and nomadic pastoral tribe on arid pastoral land. An exchange system grew up between agrarian tribes and pastoral tribes for the products such as hides, wool, milk, meat, horn and bone, and live animals from pastoral tribes for grain, peas, crafts, and tools from agrarian tribes. The exchange allowed some nomadic pastoralists to become nomadic traders to form nomadic pastoral-trade tribes. Most of the time, relations between settled agriculturalists and nomadic pastoralists-traders were harmonious with rigid boundary. The large differences in lifestyles and lands allowed settled agriculturalists and nomadic pastoralists-traders to stay in separate places peacefully without mixing for a very long time, resulting in distinctively different races between agriculturalists and pastoralists-traders. With rigid boundary between agriculturalists and pastoralists-traders, the worldview was still territorialism. The political type was tribalism ruled by tribal chiefs.

According to Nisbett et al. (2001), most subsistence research has compared herders and farmers, arguing that the independence and mobility of herding make herding cultures individualistic and that the stability and high labor demands of farming make farming cultures collectivistic. Individualism prevails in the West originated from the Middle East and Grace, while collectivism prevails in the East originated from India and China. In the study of individualism-collectivism by Hofstede et al. (2010), countries for individualism scores are 91 for USA, 89 for UK, 71 for France, 69 for Germany, 48 for India, 46 for Japan, 39 for Russia, 25 for Hong Kong (China), 20 for China, 20 for Singapore, 18 for South Korea, and 17 for Taiwan (China). According to Hofstede, individualistic cultures stress "I" consciousness. The core assumption in a culture like this is that individual is unique and independent of one another. In contrast, collectivistic cultures emphasize "we" consciousness. In a collectivistic culture, people are expected to be interdependent and to conform to the group's norms and values. The core assumption in this culture is that groups bind and mutually obligate individuals. According to Oyserman, Coon, \& Kemmelmeier (2002), the seven elements of individualism are independent, goals, compete, unique, private, self-know, and direct communicate, while the eight elements of collectivism are related, belong, duty, harmony, advice, context, hierarchy, and group.

Westerners and Easterners have different perceptions. Westerners pay attention to the focal object separated from its surrounding based on discrete perception, while Easterners attend more broadly to the overall surroundings and to the relations between the object and the field (Nisbett, 2004; Yuki et al., 2005). One typical way to identify Westerners vs. Easterners is to pair panda, monkey, and banana. Typically, Westerners pair panda and monkey for the same category (animals), while Easterners pair monkey and banana for the relationship (mon- 
key eats banana). Individualism in the West and collectivism in the East do not think alike.

Settled agriculturalists and nomadic pastoralists-traders developed different production types. The arid pastoral land brought about adventurous production type with high-profit, high risk, and low coordination frequent migration, military plundering, and risky nomadic long-distance trade. The production relation among pastoralists-traders was individualism which required individual independence in adventurous production type. The fertile agrarian land produced consolidative production type with consolidative, low risk, and high coordination agrarian irrigation and infrastructure. The production relation among agriculturalists was collectivism which required collective interdependence in consolidative production type. As a result, settled agrarian tribe developed collectivism, collectivistic territorialism worldview, and consolidative production type, while nomadic pastoral-trade tribe developed individualism, individualistic territorialism, and adventurous production type.

The egalitarian religions during the linked bands stage were transformed into hierarchical ancestor worship and high gods. Ancestor worship is defined as belief that the spirits of ancestors remain active in another realm where they may influence the living, and can be influenced by the living (Steadman, Palmer, \& Tilley, 1996). Ancestor worship allowed the hierarchical social structure to be inherited. "High gods" is defined as single, all-powerful creator deities who may be active in human affairs and supportive of human morality (Swanson, 1960). Ancestor worship and high gods appointed hierarchical social structures. Each tribe had one dominant ancestor or high god.

\subsubsection{Split Individualistic-Collectivistic Nations}

The Bronze Age started at different times at different parts of the world. The earliest started about 5,500 years ago in the Southwestern Asia. The Bronze Age ended about 3,000 years ago when the Iron Age started. The bronze technological revolution led to the invention of vehicles with spoked wheels for long-distance battle and chariots for effective weapon which effectively destroyed the boundary between the agrarian tribe and the pastoral tribe resulting in the transformation from split tribes into nations consisting of both pastoral tribes and agrarian tribes. From their homeland north of the Black Sea and the Caspian Sea between 5000 and 4800 years ago, the nomadic Yamnaya pastoralists who domesticated horses and then developed wheeled vehicles and chariots, invaded and mixed with agriculturalists, and become the ancestors of a group of people who spoke Indo-European language, including most European languages (Greek, Latin, the Romance languages of French, Spanish, Portuguese and Italian, and the Germanic, Scandinavian and Slav languages), Iranian and several languages in South Asia (Anthony, 2010). In the Middle East, the Semitic pastoralists in the large, arid desert west of Mesopotamia, stretching south from Syria into the Arabian Peninsula swept over the more fertile lands of Sumeria and what became known as Canaan and Palestine (Hetzron, 1997). 
The merge of pastoralists and agriculturalists transformed the split tribe stage into the split nation stage. Nations consisted of both agriculturalist culture and pastoralist culture without rigid boundary between agricultural culture and pastoralist culture. Humans were evolved with territorial worldview with rigid boundary to separate ingroup and outgroup. With flexible boundary, territorialism worldview is transformed into individualism worldview with basically extended outgroup without significant ingroup or collectivism with basically extended ingroup without significant outgroup. In apes, chimpanzees without rigid boundary have individualism worldview, while bonobos without rigid boundary have collectivism worldview (Wrangham, 2018; McDonald, 2012). Pastoral culture leads to individualism, and agricultural culture leads to collectivism. The worldviews of nations without rigid boundary were transformed from territorialism worldview into either individualism worldview or collectivism worldview. The nations were split into the collectivistic nations dominated and ruled by bonobo-like agricultural culture and the individualistic nations dominated and ruled by chimpanzee-like pastoral culture.

The collectivistic nations were dominated by consolidative production type with consolidative, low risk, and high coordination agrarian irrigation and infrastructure. The political production type was collectivistic authoritarianism. The nations in the East originated from India and China were dominated by consolidative production type and authoritarian collectivism.

The individualistic nations were dominated by adventurous production type with adventurous, high risk, and low coordination frequent military expansion, military plundering, and risky long-distance trade and the individualism production relation. The political type was individualistic feudalism. The nations in the West originated from the Middle East and Greece were dominated by adventurous production type and individualism.

During the split nation stage, the religion was polytheism. In polytheism, the chief deity was typically remote, and people worshiped their local deities. One typical example of polytheism is the polytheism in Canaan. Canaan, an ancient region between the River Jordan and the Mediterranean, located in the Levant region of present-day Lebanon, Syria, Jordan, and Israel. The chief deity was El. During the Bronze Age and the early Iron Age, each tribe had its own local tribal deity under El as el in the word of Israel (Davies, 2010). Israel and Judah shared Yahweh as their tribal god. The various tribal gods were more or less equal. Because of the intermarriages and alliance among these tribes, each tribe had altars for the national gods of neighboring tribes. According to archeological evidence (Stern, 2001), during this time, idols represented other religions were found commonly in Jewish homes. On the whole, Mark S. Smith shows how Israelite polytheism was a feature of Israelite religion until the seventh and sixth centuries (Smith, 2001).

\subsection{Modernity (From the Iron Age to the Industrial Age)}

- Modernity starts from the Iron Technological Revolution. 
- The other revolution in modernity is the Industrial Technological Revolution.

- Modernity corresponds to autonomous toddlerhood.

- The principal identity is human mind, and the process is rationality.

- The principal attribute is rational autonomy, and the process is exploration.

- The political systems include individualistic-collectivistic mega nations by the Iron Revolution and individualistic-collectivistic democracies by the Industrial Revolution.

- The religious systems ae monotheism and henotheism.

- The civilization is autonomous rational believing civilization.

- The major activity is autonomous rational exploration as in the Axial Age. In conventional history, modernity starts from the Renaissance and the Enlightenment period. However, the Renaissance is basically a return to classical Greek culture. As a result, modernity should start from the Axial Age when classical Greek culture prevailed. The Axial Age is the result of the formation of mega nations from the Iron Revolution. The Enlightenment is actually the neoAxial Age. Modernity consists of split individualistic-collectivistic mega nations stage and split individualistic-collectivistic mega democracies stage.

\subsubsection{Split Individualistic-Collectivistic Mega Nations}

The Iron Age (the Iron Revolution) started between 1200BCE and 600BCE, depending on the region. Iron is tougher and lighter than bronze and was used to make much better sharp objects like spears, swords, and sharp tools than bronze. The source for iron was much more abundant than bronze. The state with iron technology was strong enough with enough destructive power of iron weapons to form mega nations such as mega empires. The earliest proto-mega centralized empire is the Hittite Empire based on the advantages entailed by its high advancement on ironworking at the time (Muhly, 2003). The Hittite Empire was not very large, and did not last long. The earliest mega centralized empires were the neo-Assyrian empire (934 - 609 BCE) and neo-Babylonian empire (612 - 539 BCE). In some regions, such as China, the late bronze period and the early iron period were overlapped, so mega empires were formed in the late Bronze Age, and completely solidified in the Iron Age.

A mega empire contained many small nations and tribes with different local religions. As a result, to find a common ground for local religions, great thinkers turned inside to human mind as the source of religions. In modernity, the principal identity is human mind. The process for the human mind is consistent and logical rationality. Original early rationality is the inner logic and consistency within a system, and is not science rationality which requires the test for its generalized propositions in observations (Zhang, 2013). This early rationality is equivalent to the Comte's consistent metaphysical abstraction which evolved into science rationality in the positive scientific stage. Modernity includes both the metaphysical stage and the positive scientific stage in the Comte's three stages.

With rationality, human mind became autonomous to local religions. Rational 
autonomy became the principal attribute. The process for rational autonomy is exploration. Modernity corresponds to autonomous toddlerhood. The major activity is autonomous rational exploration that resulted in the Axial Age from about the $8^{\text {th }}$ to the $3^{\text {rd }}$ century BCE (Joas \& Bellah, 2012). The Axial Age produced the great rational thinkers to establish the new rational social orders for the mega empires. The great rational thinkers include Confucius and Laozi in China, Buddha and the writers of the Upanishads in India, Zarathustra in Iran, Isaiah, Jeremiah, and Ezekiel in the Middle East, and Socrates, Plato, and Aristotle in Greece. A famous dictum from Socrates is "the unexamined life is not worth living".

In Judaism-Christianity-Islam, the Garden of Eden represents premodernity when all people were under the authority of imaginary guardian. The tree of the knowledge of good and evil represents rationality to determine good and evil by knowledge instead of the authority of imaginary guardian. By taking the forbidden fruit from the tree of the knowledge of good and evil, people entered into autonomous rational modernity, resulting in the exploration outside of the Garden of Eden (premodernity).

In individualistic mega nations originated from the Middle East and Greece, rationality from the rational brain produced rule of law and liberty. Rule of law was originally rule for outgroup as legalized contract rule including contracts among traders from different tribes and treaties among the chiefs of different tribes. Such legalized contract rule is basically arbitrary contract. Under individualism worldview based on extended outgoup, rule of law (Haakonssen, 1996) becomes rule for all people as independent individuals. Legalized contract rule deals with discrete and independent individuals without relations. All independent and equal individuals are under one standard rule of law enforced by reward and punishment for observation and violation, respectively, of rule of law. Rule of law is important to control independent individuals fairly and equally in individualistic society.

Liberty was established by Athens around 460 BCE. In liberty, every qualified adult is entitled to compete freely which is more important than common wellbeing. Athens established the constitution which is called a democracy because it respects the interests not of the minority but of all citizens. When it was a question of settling private disputes, every citizen was equal before the law. The Roman Republic (509 - 27 BCE) combined both tyranny and democracy. The Republic was divided into the three basic parts including elected non-hereditary magistrates, a Senate to advise and consent, and popular assemblies. Instead of a king, and to guard against despotism, the Republic chose two consuls as executive magistrates appointed by the popular assembly. The two consuls represented tyranny. The Senate served as an advisory body to the consuls. Throughout most of its existence, the Roman Senate remained the domain of the wealthy. It was the embodiment of oligarchy, a lawmaking body governed by the aristocracy. The democratic part of Roman government was in the form of assemblies, in 
which the Roman people directly elected executive magistrates. The Roman Republic served as a direct model of government for the writers of the American constitution. Liberty is important to protect individuality in individualistic society.

In collectivistic mega nations originated from India and China, rationality from the rational brain produced rule of relation and division of professional. Rule of relation is derived from rule for the extended instinctive ingroup relations under collectivism worldview. The four instinctive ingroup relations in the social brain (Dunbar, 2016; Chung, 2020a) consist of family (kinship) intragroup relation to protect vulnerable children through commitment, alliance intragroup relation to protect vulnerable individuals through reciprocity, interdependent division of labor intragroup relation from interdependent specialists to protect vulnerable pregnant females through interdependence, and multigenerational intragroup relation from older leaders-mentors to protect next generation through generativity (legacy).

In East Asia (China, Japan, Korea, Vietnam, and Singapore) under the influence of Confucianism, rule of relation is expressed as "five virtues", "five cardinal relationships", and "golden mean" (Ma et al., 2016). "Five virtues" stands for benevolence (ren), righteousness (yi), courtesy (li), wisdom (zhi), and trust (xin). "Five cardinal relationships" refer to five important ethical relationships of parents-offspring, monarch-subjects, husband-wife, among siblings and among friends. "Golden mean" (the Doctrine of the Mean) means individuals should hold the attitude of moderation and avoid being extreme. The thinking of "golden mean" pays attention to the interests of the whole, avoiding being extreme, and trying to keep balance. Rule of relation is suitable for settled, well-organized, well-coordinated collective society with consolidative production type.

To collectivism worldview, the human nature for all individuals is basically good, so rule of relation instead of rule of law is needed to cultivate the basic good instinctive intragroup relations in all individuals. All connective individuals are under one standard rule of relation enforced by honor and shame for the fulfillment and unfulfillment, respectively, of rule of relation (Jiang, Lo, \& Garris, 2012).

Under collectivism, rationality produces division of professional to transform authoritarian collectivism ruled by aristocrats into professional collectivism ruled by elite professionals. In China the first emperor in the decentralized China is Yu the Great (2123 - 2025 BCE) as the founder of Xia Dynasty (2070 - 1600 $\mathrm{BCE})$. $\mathrm{Yu}$ the Great was a professional engineer who became a professional ruler because he introduced flood control benefiting people. Yu successfully devised a system of flood controls that relieved flood water, provided irrigation, and dredged riverbed. The tradition of professional rulers became an important part of Chinese traditions. The Han dynasty (206 BCE - $220 \mathrm{CE}$ ) established meritocracy. All high administrators in government had to be professionally qualified through the national examination system and the national promotion system (Tan \& Geng, 2005). 
In India, the Varna (caste) system was meritocracy based on division of professional consisting of Brahmin Varna for priests and thinkers, Kshatriya Varna for rulers and warriors, Vaishya Varna for merchants and skill workers, and Shudra Varna for labors. "Varna" means one that is adopted by choice. Everyone is considered to be born as Shudra. Through education, one becomes a Brahmin, Kshatriya or Vaishya. This completion of education is considered to be a second birth to obtain the status of "Dwija" (twice-born) for a Brahmin, Kshatriya or Vaishya. However, due to frequent foreign invasions, the Varna system became more rigid to protect the Varna system from the foreign invaders (Newar, 2016).

The Varna system is derived from the professional system in the earlier agrarian Indus Valley civilization (Wright, 2009) which was a highly professional civilization from 5000 BCE to 1900 BCE. One of the cities was Mohenjo-Daro. Mohenjo-Daro was an elaborately constructed city with streets laid out evenly at right angles and a sophisticated drainage system. The Great Bath, a central structure at the site, was heated and seems to have been a focal point for the community. The citizens were skilled in the use of metals such as copper, bronze, lead, and tin as evidenced by artworks such as the bronze statue of the Dancing Girl and by individual seals. The seals were made of terracotta and were used by merchants to stamp their goods as the professional approval. The cities did not have large buildings for governments, religions, and military protection. They were ruled apparently by low-profile peaceful professionals. The Indus Valley civilization is basically a professional eusocial civilization based on division of professional. Division of professional is suitable for settled, well-organized, well-coordinated collective society with consolidative production type.

Robust individualistic society and collectivistic society have rule of law, liberty, rule of relation, and division of professional. In individualistic society, rule of law and liberty have higher priority than rule of relation and division of professional, so rule of law can overrule rule of relation, and liberty can overrule division of professional. In collectivistic society, rule of relation and division of professional have higher priority than rule of law and liberty, so rule of relation can overrule rule of law, and division of professional can overrule liberty.

The highly centralized mega empires in the individualistic West required highly centralized and exclusive monotheism including Zoroastrianism, Christianity, and Islam. During and after the destruction of Israel and Judah by the mega empires, without traditional places to worship, the Israelite prophets looked into human mind as the source to worship. According the prophet Jeremiah, "This is the covenant I will make with the people of Israel after that time," declares the LORD. "I will put my law in their minds and write it on their hearts. I will be their God, and they will be my people." (Jeremiah 31:33) The process for human mind is rationality. To match the new all-powerful mega leaders of new mega empires, the prophets transformed polytheism into monotheism with the new consistent and logical history for monotheism, resulting in the Deuteronomist theology which involves the consistent and logical covenant between the Israe- 
lites and all-powerful monotheistic Yahweh (God) (Brueggemann, 2002).

In the Western monotheistic religions, Judaism is mostly for Israelites mostly in the political domain, Christianity is for all people mostly in the spiritual domain (the Kingdom of Heaven), and Islamism is for all people in the political and spiritual domains. Highly centralized mega empires in the collective East required highly centralized and inclusive henotheism (theism of one god) to worship a single god without denying the existence or possible existence of other deities.

About two thousand years ago, the Roman Empire based on liberal-individualism and the Han Dynasty based on professional-collectivism coexisted as the two long-lasting super powers at about the same time without much interaction. The fall of the Western Roman Empire in $476 \mathrm{CE}$ returned the West Europe back to the feudal nation stage from the mega nation stage, resulting in the loss of liberal individualism. During the 18th century, the Age of Enlightenment centered on reason as the primary source of knowledge dominated the world of ideas in Europe, resulting in the return of liberal individualism and liberal capitalism. The founder of this neo-Modernity is René Descartes (1596-1650). That "I think, therefore, I am" expresses both rationality and autonomy.

\subsubsection{Split Individualistic-Collectivistic Democracies}

The Industrial Revolution contains two stages. The first industrial revolution began in Britain in the late $18^{\text {th }}$ century. It was centered on textiles, steam power, and iron. The second industrial revolution was between 1870 and 1914 after the civil war in America. It was centered on steel, railroads, petroleum, chemicals, and electricity.

The Industrial Revolution brings about affluence and education to all people including poor people, women, and minorities who had little wealth and education before the Industrial Revolution. In the Industrial Revolution, the dramatic increase in productivity lifted most people from the poverty. The Industrial Revolution allows and requires all individuals to be educated. As a result, all people with affluence and education demand the participation in government. Derived from the ancient Greek "demokratia", democracy literally means that power (kratos) belongs to the common people (demos). In democracy, power belongs to the common people instead of dictators, inherited kings-queens, and inherited aristocrats. Democracy does not mean individual liberal democracy only. Affluence by the Industrial Revolution allows such democracy for all people.

The Industrial Revolution transforms mega nations into global democracy where power belongs to all people. The Industrial Revolution transforms capitalism into individual liberal democracy (individualism, rule of law, liberty, and affluence) for all people principally in individual liberty. Individual liberal democracy prevails mostly in the individualistic West.

Meanwhile, the Industrial Revolution transforms meritocracy into common professional democracy (collectivism, rule of relation, division of professional, and affluence) for all people principally in common wellbeing. Common professional democracy is conventionally called socialism. Common professional de- 
mocracy is naturally compatible with the collectivistic East. Common professional democracy also exists in the West due to the reaction against the excessive self-interest in individualism in the West. As a result, collectivism in the West is derived essentially from anti-individualism. In the West, in Jean-Jacques Rousseau's “The Social Contract”, Rousseau argued against the idea of class divisions in society and the idea that people should be guided by self-interest alone. Instead, he believed that each individual has a social contract with the rest of the people in society that requires them to consider the collective-interest of the group. Thomas Hobbes also argued in favor of the concept of a social contract to check self-interest. Collectivism further developed in the $19^{\text {th }}$ century with the ideas and writings of Karl Marx (Marx, 1990). Marx witnessed and expressed concern for the horrible working conditions of the early Industrial Revolution. Marx argued that working-class people should unite and collectively own and operate the businesses to avoid being exploited by the wealthy owners of the time. This was an important contribution to collectivism as an ideology because Marx was supporting the ideas of collective interest, economic equality and public ownership. The world now is split into the individual liberal democracy bloc for all people principally in individual liberty and the common professional democracy bloc for all people principally in common wellbeing.

Democracy for all people means the need for the legal, political, and economic protection of minorities to avoid majority tribalism. With the high priority of individual liberty and the low priority of common wellbeing in individual liberal democracy, the protection of minorities is particularly important. Under normal condition, minorities are protected. However, under stress, when people in majority feel their right is threatened by minorities, the people in majority through populism have a good chance by election to form majority tribalism to deplete the right of minorities (Fisher, 2018).

For the industrialized countries, adventurous production type (strength in invention, productivity, efficiency, and marketing) based on liberal individualism relation is adaptable to individual liberal democracy for individual liberty, while the (capital and labor) consolidative production type (strength in development, supply chain, economy of scale, and ration) based on professional collectivism relation is adaptable to common professional democracy for common wellbeing.

Each robust individual liberty democracy or common professional democracy has rule of law, liberty, rule of relation, and division of professional. In individual liberty democracy, rule of law and liberty have higher priority than rule of relation and division of professional, so to achieve individual liberty under stress, rule of law can overrule rule of relation, and liberty can overrule division of professional. In common professional democracy, rule of relation and division of professional have higher priority than rule of law and liberty, so to achieve common wellbeing under stress, rule of relation can overrule rule of law, and division of professional can overrule liberty.

For more than hundred years, the West has practiced dual individual liberal 
democracy consisting of individual liberal democracy core and common professional democracy complement. The instability in chaotic competitive election in individual liberal democracy can be minimized by meritocratic professional civil service as in common professional democracy. The first European power to implement a successful meritocratic civil service was the British Empire, in their administration of India: "company managers hired and promoted employees based on competitive examinations in order to prevent corruption and favoritism." (Kazin, Edwards, \& Rothman, 2010). In 1883, the system of appointments to the United States Federal Bureaucracy was revamped by the Pendleton Civil Service Reform Act, partially based on the British meritocratic civil service that had been established years earlier. The act stipulated that government jobs should be awarded on the basis of merit, through competitive exams, rather than ties to politicians or political affiliation.

Marx did not provide much guidance for how a cooperative society would operate without property, class, and state. In reality, the Soviet Union under Lenin and Stalin practiced common professional democracy based on professional collectivism ruled by cooperative professionals for all people without class conflict. The economy was the professionally planned cooperative economy based on consolidative production type consisting of development, supply chain, scale of economy, and ration. The Soviet Union had a well-developed system of professionals based on division of professional in the Soviet Union and the Eastern Europe. The Soviet Union developed the strong consolidative production type for development, supply chain, economy of scale, and ration. By the 1950s, consolidative production type allowed the Soviet Union to rapidly evolve from a mainly agrarian society into a major industrial power (Davies, 1998). The economy continued to grow afterward partially due to the skyrocketed world price of oil in the 1970s benefiting the oil-rich USSR. In terms of GDP, the Soviet Union maintained itself as the second largest economy for much of the Cold War until 1988. However, the Soviet Union neglected to develop adventurous production type as the complementary production type for invention, productivity, efficiency, and marketing until it was too late. Consequently, during the new Information Revolution in 1980's, the Soviet Union lost the competition against individual liberal democracy with adventurous production type, resulting in the breakup of the Communist bloc in Europe in 1989 and the collapse of the USSR in 1991. The breakup broke the well-developed consolidative production type, moving the economy backward, and the former European communist countries did not recover until recently.

Since the opening and reform in 1978 (Vogel, 2011), China who basically followed the Soviet Union has added adventurous production type as the complement to consolidative production type as the core, and has added individual liberal democracy on the local level as the complement as described by Daniel A. Bell (Bell, 2015). Consequently, according to the World Bank, more than 850 million Chinese people have been lifted out of extreme poverty; China's poverty 
rate fell from 88 percent in 1981 to 0.7 percent in 2015 (The World Bank Group, 2018). In China now, the private sector accounts for more than two-thirds of the economy and 90 percent of Chinese exports (43 percent of which are from foreign-owned firms) (Shan, 2019). Therefore, any robust democracy and production type have to have both the cores and the complements.

In the East, Japan with the third largest economy in the world is basically collectivistic under the strong influence of Confucianism. It has collective capitalism (Hundt \& Uttam, 2017) which has been the main policy since WWII. The state has shaped economic institutions in order to achieve specific developmental goals. Industrial policy has been the primary means of state intervention. Japan's collective capitalism relies on cooperation instead of competition as in individualistic capitalism in the West. For examples, a large manufacture company and its suppliers own each other's stocks to form interlocking manufacturer and suppliers. Many companies form such interlocking groups based on cooperation. It is difficult for the individualistic Western companies to penetrate collectivistic Japanese economy. Workers working for large businesses have job security for life, in return for loyalty and hard work based on cooperation. Politically, weak opposition makes Japan look like a one-party system by the Liberal Democratic Party (LDP) (Curtis, 2016), because Japanese do not feel strongly about opposition. The government is dominated by highly professional, powerful, and large bureaucrats (over one million employees). As a result, economically and politically, Japan is collectivistic. As shown in the Hofstede cultural dimension model (Hofstede et al., 2010) and in Varieties of Capitalism in Asia: Critical Studies of the Asia-Pacific by Hundt and Uttam (Hundt \& Uttam, 2017), most of the South and East Asian countries are collectivistic.

\subsection{Postmodernity (The Information Revolution)}

- Postmodernity is derived from the Information Revolution.

- Postmodernity corresponds to diverse childhood.

- The principal identity is other cultures, and the process is theory of mind to learn diverse cultures.

- The principal attribute is diversity, and the process is learning.

- The political system includes pluralistic individualistic-collectivistic democracies.

- The religious system is religious pluralism.

- The civilization is diverse autonomous rational believing civilization.

- The major activity is the learning of diversity.

The Information Revolution (Orton, 2009) occurred in the second half of the 20th century with the proliferation of digital computers, digital record, personal computers, the internet, and information and communications technology. Development of technologies (such as computers, digital communication, and microchips) led to dramatic reduction in the cost of obtaining, processing, storing, and transmitting information in all forms (text, graphics, audio, and video). The 
Information Revolution also combines robotics, artificial intelligence, nanotechnology, quantum computing, biotechnology, the Internet of Things (IoT), decentralized consensus, 3D printing, and autonomous vehicles.

With the proliferation of information to produce diversity from the Information Revolution, postmodernism is a broad movement that developed in the second half of the $20^{\text {th }}$ century across philosophy, the arts, architecture, and criticism, marking a departure from the consistent and logical modernism (Lyotard, 1984; Lukas, 2013). Postmodernists claim that it is impossible for anyone to have objective and neutral knowledge of another culture. This view comes from the notion that we all interpret the world around us in our own way according to our language, cultural background, and personal experiences. In other words, everybody has their own views based on his or her social and personal contexts. Reality is in the mind of the beholder. Reality is what's real to me, and I construct my own reality in my mind. People are not able to think independently because they are defined by their culture. We cannot judge things in another culture or another person's life, because our reality may be different from theirs. Postmodernism is skeptical toward modernism assumptions about knowledge, truth, and reason. Postmodernism embraces relativism where truth and moral values are not absolute but are relative to the persons or groups holding them. To postmodernism, there is no definitive progress in society. While modernism was ultimately founded on a utopianism that upheld certain universal truths, postmodernism rejected and deconstructed the notion of truth altogether.

Postmodernity corresponds to diverse childhood. The principal identity is other cultures. The process for the identity of other cultures is theory of mind where other cultures have their own minds. The principal attribute is diversity. The process for the attribute of diversity is learning diversity without too much judgement. Postmodernity is diverse autonomous rational believing civilization. Postmodernism recognizes that different cultures have different perspectives, worldviews, religions, politics, and economy. It is better to recognize, respect, and understand other cultures from theory of mind than to ignore, disrespect, and demonize other cultures from the absence of theory of mind.

In politics, postmodernism raises the status of marginalized groups whom the dominant culture has excluded politically and economically. Postmodernism also concerns about economic progress which can damage nature, and threaten our future. Postmodern democracies became democratic pluralism of individual liberal democracy and common professional democracy. In postmodern democratic pluralism, un-democracy rejects democracy, progressive democracy accepts democratic pluralism more than conservative democracy, fundamental democracy rejects democratic pluralism entirely, and extreme democracy rejects entirely and violently democratic pluralism. Individualistic democratic pluralism promotes more individual liberty than common wellbeing, while collectivistic democratic pluralism promotes more common wellbeing than individual liberty.

Postmodern religions became religious pluralism. In religious pluralism, athe- 
ism rejects any theism, progressive postmodern religion accepts religious pluralism more than conservative postmodern religion, fundamental religions reject religious pluralism entirely, and extreme religions violently reject religious pluralism. Individualistic religious pluralism promotes individual liberty of religions, while collectivistic religious pluralism promotes cooperation among religions. A typical example of religious pluralism is from Billy Graham. Billy Graham, the most respected Christian evangelist in the world, said, "I used to play God but I can't do that anymore. I used to believe that pagans in far-off countries were lost and were going to hell-if they did not have the Gospel of Jesus Christ preached to them. I no longer believe that," he said carefully. "I believe that there are other ways of recognizing the existence of God-through nature, for instance-and plenty of other opportunities, therefore, of saying 'yes' to God." (Beam, 1978).

\subsection{Eu-Modernity (The Intelligence Revolution)}

- Eu-modernity is derived from the Intelligence Revolution.

- Eu-modernity corresponds to eusocial adulthood.

- Postmodernism is about diversity, and eu-modernism is about the relations in diversity.

- The principal identity is interconnected world, and the process for the identity of the interconnected world is internationalization to establish relations in diversity.

- The principal attribute is eusociality, and the process is interdependence, multigenerational generality, and intergroup generosity.

- The political system is interdependent democracy, and the religious system is interdependent religion.

- The civilization is eusocial diverse autonomous rational believing civilization.

- The major activity is eusociality with interdependent division of labor between individualism and collectivism, multigenerational generality, and intergroup generosity.

Eu-modernity is eusocial-modernity. The world now is undergoing the Intelligence Revolution with artificial intelligence, big data, automation, enormous data collection, and digital connection everywhere (Makridakis, 2017). Artificial intelligence (AI) is defined as the ability for computers to perceive, learn, reason, and assist in decision-making to solve problems in ways that are similar to humans. AI can be deployed across a range of business functions to take over manual, repetitive and time-consuming tasks undertaken by employees. It can also provide insight into data. The Intelligence Revolution brings extensive changes that will also affect all aspects of our society and life. In addition, its impact on firms and employment will be considerable, which results in richly interconnected organizations with decision making based on the analysis and exploitation of "big" data and intensified global competition among firms. People will be capable of buying goods and obtaining services from anywhere in the world using the Internet, and exploiting the unlimited, additional benefits that will open 
through the widespread usage of AI inventions.

With ubiquitous and meaningful connections from the Information Revolution and the Intelligence Revolution, the world becomes highly interconnected in information and production. The usage of ubiquitous global information network in terms of e-commerce, instant news, and social media becomes necessary part of daily life for people in developed countries and many developing countries. Today, very few products are manufactured entirely in a single country, and people consume products daily from all over the world.

In eu-modernity, the principal identity is the interconnected world. The process for the interconnected world can be globalization (Huntington, 1996; Fukuyama, 1992) or internationalization (Daly, 1999). Globalization globalizes diverse cultures into one globalized culture. For examples, according to the book "The Clash of Civilizations and the Remaking of World Order" (1996) (Huntington, 1996), political scientist Samuel Huntington proposed that in the twenty first century in the post-Cold War world, a clash of civilizations would replace the clashes among nation-states in the nineteenth century and among ideologies in the twentieth century. According to Huntington, the West, and especially the United States, which has always been a missionary nation, believe that the nonWestern peoples should commit themselves to the Western values of democracy, free markets, limited government, human rights, individualism, rule of law, and should embody these values in their institutions.

Since the end of the Cold War in early 1990s, liberal democracy has become a major political system as described in "The End of History" (Fukuyama, 1992) by political scientist Francis Fukuyama who claimed that the human history was ended with liberal democracy and private free market economy. Sociologist Salvatore Babones began to use the historical Chinese concept of tianxia ("all under heaven") to describe the structure of the millennial world-system as an American tianxia that has endogenized the entire world-economy under a single, American-dominated political system (Babones, 2017). Liberal individualism has become the leitmotif of an emerging order in which people of all nationalities seek a share in the economic, cultural, and political system that is America writ large.

However, liberal democracy has not dominated the world. Futile globalization into liberal democracy is described by Sociologist Koert Debeuf in "Tribalization: Why war is coming" (Debeuf, 2019), which describes that the end of globalization is tribalization which brings suffering and chaos in Syria, Libya, Afghanistan, and Iraq. Individual liberal democracy for all people and common professional democracy for all people do not want tribalism. Unfortunately, the exports of tribalism continue to destabilize each other. Different cultures have different ways to deal with their problems. There is no global way to deal with problems. Individualism where individual liberty is important and collectivism where common wellbeing is important do not think alike. The alternative to globalization is internationalization as proposed by Sociologist Herman Daly (Daly, 1999). According to Herman Daly, globalization, considered by many to be the inevita- 
ble wave of the future, is frequently confused with internationalization, but is in fact something totally different. Internationalization refers to the increasing importance of interdependent relations between nations: international trade, international treaties, alliances, protocols, etc. Internationalization recognizes and accepts diversity in postmodernity, and allows different cultures to deal with their problems differently. Without exporting tribalism to destabilize each other, individual liberty democracy can improve common wellbeing, while common professional democracy can improve individual liberty.

For eu-modernity, the principal identity is the interconnected world, and the process for the identity of the interconnected world is internationalization to establish relations in diversity. Confucius said: "Noble persons seek harmony but not sameness. Petty persons seek sameness but not harmony." (Analects 13:23). Eu-modernity corresponds to eusocial adulthood. The attribute of eu-modernity is eusociality, and the process for sociality-attribute consists of interdependent division of labor, multigenerational generativity, and intergroup generosity.

\subsubsection{Emerging Eu-Modernity}

Presently, the civilization is emerging eu-modernity, corresponding to emerging adulthood between childhood and full-fledged adulthood (Arnett, 2000). The attribute of emerging eu-modernity is emerging eusociality. The process for emerging eu-modernity consists of emerging interdependent division of labor, multigenerational generativity, and intergroup generosity instead of full-fledged interdependent division of labor, multigenerational generativity, and intergroup generosity. Emerging interdependent division of labor is the recognition of interdependent division of labor in democracies, economies, and production types in the $21^{\text {st }}$ century.

\section{1) Emerging Interdependent Democracies and Economies}

Toward the end of the twentieth century after the end of the Cold War and the collapse of the Soviet Union in 1991, the world felt only liberal democracy and free market economy would start the twenty-first century and all future centuries as claimed by political scientist Francis Fukuyama in "The End of History" (Fukuyama, 1992). According to Francis Fukuyama, individual liberal democracy for individual liberty would prevail over common professional democracy for common wellbeing, and individualistic free market economy would overmatch collective planned economy. The twenty-first century turns out to be quite eventful for liberal democracy and free market economy. Individual liberal democracy for individual liberty faced the terrorism crisis in the first year 2001 of the twenty-first century and the subsequent long destructive war in the Middle East. Individualistic market economy faced the disastrous financial crisis in 2008. How did individual liberal democracy and individualistic market economy response to such crises?

The Patriot Act was passed by the US Congress with bipartisan support (357 66 vote in the House and 98 - 1 vote in the Senate) and signed into law by President George W. Bush on October 26, 2001, just weeks after the September 11 
terrorist attacks against the United States (Etzioni, 2004). The Patriot Act allows law enforcement to use surveillance and wiretapping to investigate terror-related crimes. A major player in the Patriot Act was the National Security Agency (NSA) which gathered mass digital phone data from phone companies with permission from a federal court. The NSA became the professional arm of the Patriot Act to do digital surveillance and analysis to supplement people's surveillance and analysis which were often unprofessional and intrusive. Such digital surveillance and analysis allowed the Patriot Act to detect and break terrorists' networks and acts quietly, precisely, efficiently, and professionally. In 2004 testimony before the United States Senate Committee on the Judiciary, FBI Director Robert Mueller said, "the Patriot Act has proved extraordinarily beneficial in the war on terrorism and has changed the way the FBI does business. Many of our counterterrorism successes, in fact, are the direct results of provisions included in the Act." Consequently, the Patriot Act turned individual liberal democracy for individual liberty into common professional democracy for common wellbeing. A systemic weakness of individual liberal democracy is the social chaos caused by terrorists. Individual liberal democracy depends on common professional democracy to stop terrorism. In this way, liberty is protected under the safety by common professional democracy. The Patriot Act demonstrates politically the interdependence between individual liberal democracy for individual liberty and common professional democracy for common wellbeing.

The American Recovery and Reinvestment Act (ARRA) as a stimulus package was passed by the Congress and signed into law by President Barack Obama in February 2009 in response to the disastrous financial crisis in 2008. It was a necessary follow-up to President George W. Bush's 2008 plan as the Troubled Asset Recovery Program (TARP) ended the 2008 financial crisis by bailing out large banks. The objectives of the ARRA were to save existing jobs, create new ones, provide temporary relief programs for those most affected by the recession, and invest in infrastructure, education, health, and renewable energy. The TARP and the ARRA basically transformed individualistic free market economy into collective planned economy. The financial crisis from the excessive financial speculation was predicted by Karl Marx in the mid-nineteenth century (Panitch, 2009). Financial crisis from excessive speculation is a systemic weakness of free market economy. Free market economy depends on collective planned economy to rescue it from financial crisis. In February 2009, the cover of Newsweek announced, "WE ARE ALL SOCIALISTS NOW." (Meacham, 2009) Canada's Financial Post also proclaimed, "Bailout Marks Karl Marx's Comeback.” (Masse, 2008) Free market economy is protected under the collective economic effort from collective planned economy. The TARP and the ARRA demonstrates economically the interdependence between individualistic free market economy and collective planned economy.

Mentally, under individual liberty, people are happy due to liberty, but they are prone to chaos and fragile mentality without close relations with others 
(Grossmann \& Kross, 2010). Under professional collectivism, people are serious due to professionalism and restriction, but they are stable and durable by close relations with others. Moderate liberty is independence and happiness, but excessive liberty without professionalism (expertise) is chaos as pointed out by Thomas M. Nichols in "The Death of Expertise: The Campaign against Established Knowledge and Why it Matters" (Nichols, 2017). Moderate professionalism is convenience and safety, but excessive professionalism is restriction. Liberal individualism and professional collectivism help each other to moderate liberty and professionalism. Mentally, liberal individualism and professional collectivism are interdependent. Based on theory of mind, people in liberal individualism and professional collectivism have to recognize, respect, and understand each other's mind and each other's baseline.

Politically in crisis, people under liberal individualism can detect widespread crisis faster due to individual initiative, but they are slower in stopping the widespread crisis due to the insufficient collective effort, while people under professional collectivism may detect widespread crisis slower due to the insufficient individual initiative, but they are faster in stopping widespread crisis due to collective effort. The East under professional collectivism managed to overcome the financial crisis in 2008 better than in the West under liberal individualism. In the same way, the East is managing to overcome Covid-19 better than the West. It is important for liberal individualism and professional collectivism to work together during crisis. People should use different approaches in the different stages. In the early stage of production and widespread crisis, the approach of liberal individualism takes the lead in the breakthrough invention in production and detection in widespread crisis. In the late stage of production and widespread crisis, the approach of professional collectivism takes the lead in development, supply chain, economy of scale, and ration and in the overcoming of crisis. The 2010s were the hottest decade on record ( $\mathrm{Wu}, 2020)$. Global warming crisis was first detected by liberal individualism, and can be overcome by professional collectivism. In the past, widespread recession crises were overcome by professional collectivism, and in the future, such widespread recession crises will be overcome by professional collectivism. In crisis, liberal individualism and professional collectivism are interdependent.

Now in the world, all people are interconnected. Crisis in one area can be easily spread to other area. In other words, the world is facing continuous crises, some small and some large. Human society needs artificial intelligence to detect and to overcome such continuous crises. The global warming crisis and the Covid-19 crisis accelerate the transition to the intelligence age from the industrial-information age. It is similar to the acceleration of the transition from the Bronze Age to the iron age in 1177 BEC due to the drought-unrest crisis (Cline, 2014).

\section{2) Emerging Interdependent Production Types}

Meanwhile, the extensive trade and investment between the West represented 
by the European Union and North America and the East represented by the East and South Asian countries started from 1960's, and have accelerated in the twenty-first century since China became a member of the World Trade Organization. The West was much more advanced in industry than the East, and had both adventurous production type and consolidative production type. The West, particularly America has outsourced the low-profit consolidative production type (development, supply chain, economy of scale, and ration) to the East, and kept the high-profit adventurous production type (invention, productivity, efficiency, and marketing) in the West. The West imports the consolidative production products which require low-profit development, supply chain, economy of scale, and ration from the East. The East imports the high-profit adventurous production products and services which require invention, productivity, efficiency, and marketing from the West. Essentially, The West imports low-profit mature medium-low-technology, out-sourcing, and contract manufacturing products from the East, and the East imports high-profit new high-technology products and services from the West. Both sides have grown economically from the trade and investment.

After about sixty years of such extensive globalization, the West becomes very strong in adventurous production type and deficient in consolidative production type, while the East becomes very strong in consolidative production type and deficient in adventurous production type. The individualistic West depends on the collectivistic East for the products from low-profit development, supply chain, economy of scale, and ration, while the East depends on the West for the products from high-profit invention, productivity, efficiency, and marketing. The result is the interdependent individualism-collectivism. For examples, during the Covid-19 crisis, the West has to rely on the East with development, supply chain, economy of scale, and ration to mass produce the products for medical protection equipment. At the same time, the East has to rely on the West for the products and services in the most advanced technology. Adventurous production type in the West and consolidative production type in the East are interdependent.

The education in the East aims for consolidative production type in terms of gathering and applying knowledge instead of inventing knowledge. For examples, to test gathering and applying knowledge, the Program for International Student Assessment (PISA) is an international assessment that measures 15-yearold students' reading, mathematics, and science literacy every three years. In PISA 2018 (OECD, 2019), children from the East Asian countries ranked high in all three subjects. The top five in Mathematics are China, Singapore, Macau China, Hong Kong China, and Chinese Taipei. For the university education as shown in Best Global Universities Rankings by US News \& World Report (US News \& World Report, 2019), America has many top 10 universities in science, while China has many top 10 universities in engineering. The education in the West aims for adventurous production type, while the education in the East aims 
for consolidative production type.

The Intelligence Revolution started in the West. The East has made considerable progress in AI as described by Kai-Fu Lee (Lee, 2018) in "AI Superpowers: China, Silicon Valley, and the New World Order". Lee describes how China is rapidly moving forward to become a global leader in AI. In 2019, Daniel Castro, Michael McLaughlin, and Eline Chivot (Castro, McLaughlin, \& Chivot, 2019) compares China, the European Union, and the United States in terms of their relative standing in the AI economy by examining six categories of metricstalent, research, development, adoption, data, and hardware. Overall, the United States currently leads in AI, with China rapidly catching up, and the European Union behind both. The United States leads in four of the six categories of metrics (talent, research, development, and hardware), China leads in two (adoption and data), and the European Union leads in none-although it is closely behind the United States in talent. Out of 100 total available points in this report's scoring methodology, the United States leads with 44.2 points, followed by China with 32.3 and the European Union with 23.5. Nonetheless, in the future, when controlling for the size of the labor force in the three regions, the current US lead becomes even larger, while China drops to third place, behind the European Union.

As in other technologies, in AI, the West is strong in adventurous production type, and the East is strong in consolidative production type including adoption and data. Because AI is still in the stage of invention, the West is strong in talent, research, development, and hardware which constitute the core technology of AI. The East certainly depends on the West for the products and services from invention, productivity, efficiency, and marketing. The West depends on the East for the products from development, supply chain, economy of scale, and ration. For AI, it means that no matter where core AI technological processes are being performed in the West, the AI products are being physically fabricated in the East (Domashneva, 2020). The East makes a very good use of adoption and data in terms of consolidative production types to make life convenient and safe, even though the core technologies belong to the West. Consequently, in the Intelligence Revolution, the West and the East are interdependent. In fact, the interdependent coexistence of adventurous production type and consolidative production type already exists in "Chimerica" to describe the symbiotic relationship between China and the United States according to Niall Ferguson (Ferguson, 2008).

\subsubsection{Full-Fledged Eu-Modernity}

Emerging eu-modernity is confusing. However, going back to postmodern playfulness and affectation about diversity or going further back to modern simple rationality is a poor option in this highly connected diverse world. The postmodern playfulness and affectation about diversity or modern simple rationality cannot deal with real social relations, social problems, and social responsibilities in 
this this highly connected diverse world. It is necessary to find relations in diversity. The end of diverse postmodernity and emerging eu-modernity leads to the start of eusocial eu-modernity. The transformation from emerging eu-modernity to full-fledged eu-modernity requires the establishments of various rules, concepts, and organizations in politics, boundary, economy, and religion.

\section{1) Interdependent Democracies}

Politically, the transformation from emerging interdependent division of labor between individualistic West and the collectivistic East requires interdependent democracy based on interdependent division of labor between individual liberal democracy and common professional democracy. Interdependent democracy establishes the bases for rule of relation, rule of law, liberty for debates and votes, and professional organizations to deal with various issues. Rule of relation is based on the international community of common destiny as expressed by Chinese government (Zhang, 2018). The common destiny provides the base for international cooperation. Rule of law for the rights to life, liberty, and equality for individuals is based on the Universal Declaration of Human Rights by the United Nations written mostly by American government (Roosevelt et al., 2001). The United Nations provides the liberty for debates and votes and the professional organizations to deal with various issues professionally. Under the international rules and organizations, different nations can govern themselves under different civilizations independently to avoid civilizational conflict.

\section{2) Interdependent Production Types}

Economically, the transformation from emerging into full-fledged interdependence between adventurous production type in the West and consolidative production type in the East requires interdependent economy. The most important rule for interdependent economy is free trade between adventurous production type in the West and consolidative production type in the East. Sanction and decoupling hurt both sides in this highly interlocking interdependence, and bring down the world economy. With free trade, it is possible to find a fair division of labor between the West and the East to mutual benefit. It is also possible to help each other diversify to mutual benefit. Sanction and decoupling hurt the world economy which people cannot afford during the global crises.

\section{3) The 12 International Regional Defense Communities}

The establishment of the religious-geographic boundaries ended the religious war in the Thirty Years' War among Protestant and Catholic states. In the same way, the establishment of the cultural-geographic boundaries will end the civilizational clash among civilizational types. As mentioned previously (Chung, 2017, 2020a), one solution to the civilizational clash is the establishment of twelve international regional defense communities in the "International Regional Defense Community Organization" (the IRDCO) based on rule of boundary from the "Monroe Doctrine" to prevent the outside military intervention from hegemons. Every country in the world belongs to an international regional defense community. The common identities of a regional community include some or all of the shared geography region, shared existing regional international organization, 
shared dominant cultural-religion, shard dominant language, and shared dominant worldview. Each regional community has at least one economically strong country for its protection and strength. The 12 communities in the International Regional Defense Community Organization (IRDCO) with 195 states (The United Nations, 2019) are as follows and in Table 6.

\section{The North American Community}

Canada, Mexico, the USA

\section{The South American Community}

Antigua and Barbuda, Argentina, Bahamas, Barbados, Belize, Bolivia, Brazil, Chile, Colombia, Costa Rica, Cuba, Dominica, Dominican Republic, Ecuador, El Salvador, Grenada, Guatemala, Guyana, Haiti, Honduras, Jamaica, Nicaragua, Panama, Paraguay, Peru, Saint Kitts and Nevis, Saint Lucia, Saint Vincent and The Grenadines, Suriname, Trinidad and Tobago, Uruguay, Venezuela

The East Asian Community

China, Japan, Mongolia, Philippines, the Republic of Korea, the Democratic People's Republic of Korea, Viet Nam

\section{The South Asian Community}

Bangladesh, Bhutan, Brunei, Cambodia, Laos, Malaysia, Singapore, India, Indonesia, Maldives, Myanmar, Nepal, Sri Lanka, Thailand, Timor-Leste

\section{The Midwest Asian Community}

Afghanistan, Iran, Iraq, Pakistan, Syria, Turkey

\section{The Southwest Asian Community}

Bahrain, Israel, Jordan, Lebanon, Kuwait, Oman, Palestine, Qatar, Saudi Arabia, the United Arab Emirates, Yemen

The Eurasian Community

Armenia, Azerbaijan, Belarus, Georgia, Kazakhstan, Kyrgyzstan, Russia, Tajikistan, Turkmenistan, Uzbekistan

Table 6. The International Regional Defense Community Organization (IRDCO).

\begin{tabular}{|c|c|c|c|c|}
\hline regional community & major country & major existing organization & major cultural-religious influence & major languages \\
\hline North American & USA & NAFTA & Christianity & English-Spanish \\
\hline South American & Brazil & OAS & Christianity & Spanish-Portuguese \\
\hline East Asian & China & & Confucianism & mixed languages \\
\hline South Asian & India & ASEAN & Indian culture & mixed language \\
\hline Midwest Asian & Turkey & & Islam & mixed language \\
\hline Southwest Asian & Saudi Arabia & Arab League & Islam & Arabic \\
\hline Eurasian & Russia & EAEU & Christianity-Islam & Russian \\
\hline West European & Germany-France & EU & Christianity & mixed language \\
\hline North African & Egypt & Arab League, ECOWAS & Islam & mixed language \\
\hline West African & Nigeria & ECOWAS and ECCAS & Christianity & mixed language \\
\hline East-South African & South Africa & COMESA, EAC, and SADC & Christianity & mixed language \\
\hline Pacific Islands Forum & Australia & Pacific Islands Forum Community & Christianity & English \\
\hline
\end{tabular}




\section{The West European Community}

Albania, Andorra. Austria. Belgium. Bosnia and Herzegovina, Bulgaria. Croatia. Cyprus. Czech Republic, Denmark, Estonia, Finland, France, Germany, Greece, Hungary, Iceland, Ireland, Italy, Latvia, Liechtenstein, Lithuania, Luxembourg, Malta, Moldova, Monaco, Montenegro, Netherlands, North Macedonia, Norway, Poland, Portugal, Romania, San Marino, Serbia, Slovakia, Slovenia, Spain, Sweden, Switzerland, Ukraine, the United Kingdom, Vatican City

The North African Community

Algeria, Comoros, Burkina Faso, Djibouti, Egypt, Gambia, Guinea, Guinea-Bissau, Libya, Mali, Mauritania, Morocco, Niger, Senegal, Sierra Leone, Somalia, Sudan, Tunisia

The West African Community

Benin, Cape Verde, Cameroon, Central African Republic, Chad, Côte d'Ivoire, Democratic Republic of the Congo, Equatorial Guinea, Gabon, Ghana, Liberia, Nigeria, Republic of the Congo, São Tomé and Príncipe, Togo

The East-South African Community

Angola, Botswana, Burundi, Eritrea, Eswatini, Ethiopia, Kenya, Lesotho. Madagascar, Malawi. Mauritius, Mozambique, Namibia, Rwanda, Seychelles, South Africa, South Sudan, Tanzania, Uganda, Zambia, Zimbabwe

Pacific Islands Forum Community

Australia, Fiji, Kiribati, Marshall Islands, Micronesia, Nauru, New Zealand, Palau, Papua New Guinea, Samoa, Solomon Islands, Tonga, Tuvalu, Vanuatu

Five (Brazil, Russia, India, China, and South Africa) of the twelve major countries in the IRDCO are in BRICS which is a major international community. With the territorial regional protective boundary, each regional community enforces the "Monroe Doctrine" that forbids military intrusion from the countries outside of a regional community except the intervention approved by the United Nations. As a result, all overseas military bases as the military intrusion from the countries outside of a regional community have to be abolished. All defense treaties connected to the countries outside of a regional community also have to be ended. All intercontinental ballistic missiles have to be eliminated. The numbers of aircraft carriers have to be strictly limited to few aircraft carriers according to the area of adjacent oceans. Horrible inhuman nuclear weapons have to be abolished. The regional communities which are for military defense allow individual nations to maintain all international economic treaties inside and outside of the communities. Different regional communities will have different degrees of economic cooperation within the communities. The International Regional Defense Community Organization provides the permanent world peace and stability.

\section{4) Interdependent Cares}

Interdependent cares include intergroup generosity and multigenerational generativity. Generosity and generativity are different. Intergroup generosity involves totally unrelated (stranger) social group. Independent individualistic individuals do not differentiate different groups much less than interdependent 
collectivistic individuals in a social group, so individualism favors intergroup care (Henrich, 2015). Emotional individuals (indulgent individuals) in individualistic society particularly favor intergroup generosity as such generosity diminishes one's wellbeing without foreseeable return other than good feeling in giving (Guo, Liu, Li, \& Qiao, 2018).

Multigenerational generativity involves unseen future generations usually within a social group. Interdependent collectivistic individuals care about the future of their social group, so collectivism favors long-term multigenerational generativity. In the Hofstede's six cultural dimensions (Hofstede et al., 2010) for individualism versus collectivism (IDV), power distance index (PDI), masculinity versus femininity (MAS), uncertainty avoidance index (UAI), long term orientation versus short term normative orientation (LTO), and indulgence versus restraint (IVR),, the culture under collectivistic Confucianism has extremely and uniquely strong long-term orientation based on pious genealogical linkage where genealogical linkage is respected. It rejects individual immortality that disrespects genealogical linkage. The top positions for LTO are occupied by China and Japan and the Four Little Dragons (Hong Kong (China), Taiwan (China), South Korea, and Singapore). Long-term orientation is multigenerational generativity.

As a result, interdependent care involves the interdependent division of labor between individualistic intergroup generosity and collectivistic multigenerational generativity to fulfill other groups' needs and the future generations' needs. To establish international interdependent care need the individualistic West and the collectivistic East to work together to establish international organizations for intergroup generosity and multigenerational generativity.

\section{5) Eusocial Religions}

Religion is an important part of civilization, so it is important to have interdependent religion in eu-modernity. In interdependent religion, humans and the supernatural produce imaginary guardians interdependently through the interdependent division of labor between human theory of imaginary mind and supernatural providence. By theory of imaginary mind, different believers reach different imaginary guardians, while the supernatural uses different providences to participate in different imaginary guardians as the equation below for the interdependent religious channel from both ends of the equation.

human $\leftrightarrow$ theory of imaginary mind $\leftrightarrow$ imaginary guardian $\leftrightarrow$ providence $\leftrightarrow$ supernatural

The interdependent religious channel in the equation is the channel between human and the supernatural.

For examples, in the individualistic West, each adult is independent in society, so independent individuals in society in the Western religions (Judaism, Christianity, and Islam) have great needs for imaginary loving parents as their imaginary guardians to take care of all their needs, including psychological, spiritual, political, and economical needs (Chung, 2018). The parent-child relation is de- 
scribed in the Bible as "yet to all who did receive him, to those who believed in his name, he gave the right to become children of Gods (John 1:12)". According to Apostle Paul, "The Spirit you received does not make you slaves, so that you live in fear again; rather, the Spirit you received brought about your adoption to sonship. And by him we cry, "Abba, Father." The Spirit himself testifies with our spirit that we are God's children. Now if we are children, then we are heirsheirs of God and co-heirs with Christ, if indeed we share in his sufferings in order that we may also share in his glory. (Romans 8:15-17)"

At severe psychological situations, they turn to imaginary parent-guardian to comfort, rescue, or guide them. Such comfort, rescue, and guidance can be seen in a famous psalm of David. "The LORD is my shepherd, I lack nothing. He makes me lie down in green pastures, he leads me beside quiet waters, he refreshes my soul. He guides me along the right paths for his name's sake. Even though I walk through the darkest valley, I will fear no evil, for you are with me; your rod and your staff, they comfort me. You prepare a table before me in the presence of my enemies. You anoint my head with oil; my cup overflows. Surely your goodness and love will follow me all the days of my life, and I will dwell in the house of the LORD forever." (Psalm 23) As a result, the supernatural providences participate in the imaginary guardians for these parent-child relations. This emotional personal imaginary guardian as intimate parent is important to maintain individualism, because individualistic individuals can maintain their individualism without the need for emotional connection with society. The study by Cohen and Hill on individualism in Jews, Catholics, and Protestants in America shows that Protestants are most individualistic by focusing on personal God instead of extrinsic religiosity for community and ritual (Cohen \& Hill, 2007).

In the collectivistic East, each adult is a part of collective group, so interdependent individuals in the Eastern religions (Hinduism, Buddhism, Confucianism, and Daoism) have no great needs for imaginary parents as their imaginary guardians. The collective relations in their collective groups take care of their psychological and spiritual needs in terms of kinship, friendship, multigenerational large family with the same ancestor, hometown, country, and nature. At severe psychological situations, they turn to psychological meditations to adjust calmly their brains without the emotional imaginary parent-guardian as in the Western religions (Tsai, 2007; Tsai, Miao, \& Seppala, 2007). However, collective groups in the Eastern religions need imaginary impersonal just world as their imaginary guardians in the belief of a just world (BJW) (Cohen, Wu, \& Miller, 2016). As a result, the supernatural providences participate in the imaginary guardians for just world-inhabitant relations.

The individualistic Western imaginary parent-guardian and the collectivistic Eastern just world-guardian are interdependent as no one is completely individualistic or collectivistic. People sometimes need imaginary guardian as personal loving parent, and people sometimes need imaginary guardian as impersonal 
just world. As a result, interdependent religion involves interdependent divisions of labor between individualism and collectivism and between human theory of imaginary mind and supernatural providence, resulting in interdependent imaginary loving parent-just world guardian. All major religions can work together to establish eusocial religions consisting of interdependent imaginary parentruler guardian, multigenerational generativity, and intergroup generosity.

\section{Summary and Conclusion}

In summary, in this paper, the Auguste Comte's parallel human-civilizational developments in the early nineteenth century are broadened and updated for the twenty-first century. Comte establishes the parallel between European civilizational development as the law of three stages (the theological stage, the metaphysical stage, and the positive scientific stage) and human development (childhood, adolescence, and adulthood). He holds that each individual human develops from the stage of a devout believer in childhood as in the theological stage, to a critical metaphysician to question the abstract notions of existence in adolescence as in the metaphysical stage, and to a natural philosopher in adulthood as in the positive scientific stage. The Comte's parallel human-civilizational developments are broadened to include collectivism-individualism, human evolution, and developmental psychology from Erikson's psychosocial development, and are updated to include the stages after the nineteenth century.

This paper proposes the parallel directional developmental psychologies between human developmental psychology and civilizational developmental psychology. Human grows directionally in the body-mind domain through the interaction between genes and environments, while civilization grows directionally in the political-economic domain through the interaction between technological revolutions and societies. Both developments follow the proposed identity development derived from the Erikson's psychosocial (ego-social) development. In the identity development, each stage has principal identity and its process and attribute and its process. The four stages in the human identity development are infancy, toddlerhood, childhood, and adulthood. In infancy, the principal identity is parent and the process for parent-identity is parent-recognition. The attribute is belief, and the process for belief-attribute is belief in parent. An infant is a believer. In toddlerhood, the principal identity is self and the process for self-identity is self-recognition. The attribute is autonomy, and the process for autonomy-attribute is exploration. A toddler is an autonomous believer. In childhood, the principal identity is other people, and the process for the other-peopleidentity is theory of mind to learn diverse perspectives. The attribute is diversity, and the process for diversity-attribute is learning. In adulthood, the principal identity is society, and the process for society-identity is sociality to establish relations in diversity. The attribute is eusociality, and the process for eusociality is interdependent division of labor, multigenerational generativity, and intergroup generosity. 
The four stages in the civilizational identity development are premodernity, modernity, postmodernity, and eu-modernity. In premodernity (band by the Upper Paleolithic Revolution, tribe by the Agricultural-Pastoral Revolution, and nation by the Bronze Revolution), the principal identity is imaginary guardian, and the process for imaginary-guardian-identity is theory of imaginary mind. The attribute is belief, and the process for belief-attribute is belief in imaginary guardian. Premodernity is a believing civilization. Premodernity is equivalent to Comte's theological stage. In modernity (mega nation by the Iron Revolution and democracy by the Industrial Revolution), the principal identity is human mind and the process for human-mind-identity is rationality by the rational brain. The attribute is rational autonomy, and the process for rational-autonomy-attribute is exploration. Modernity is autonomous rational believing civilization. Modernity is equivalent to the combination of the Comte's metaphysical stage and positive scientific stage, In postmodernity (pluralistic democracy by the Information Revolution), the principal identity is other cultures, and the process for the other-cultures-identity is theory of mind to learn diverse cultures. The attribute is diversity, and the process for diversity-attribute is learning. In eu-modernity (interdependent democracy by the Intelligence Revolution), the principal identity is interconnected world, and the process for interconnected-world-identity is internationalization to establish relations in diversity. The attribute is eusociality, and the process for eusociality is interdependent division of labor between individualism and collectivism, multigenerational generativity, and intergroup generosity to establish eusociality in eu-modernity.

In human biological evolution, the eusocial hunter-gatherer band was evolved to have the interdependent division of labor between hunters and gathers, multigenerational generativity, and intergroup generosity. The foundation of the interdependent division of labor is theory of mind for hunters and gatherers to recognize, respect, and understand each other's mind in terms of different hunter's mind and gatherer's mind.

Premodernity starts with linked hunter-gatherer band derived from the Upper Paleolithic Revolution. The agrarian-pastoral revolution split hunter-gatherer band into nomadic pastoral tribe and settled agrarian tribe. Pastoralists developed individualism, while agriculturalists developed collectivism as shown by Richard E. Nisbett.

In the Bronze Age, pastoralists with horse-powered wheeled vehicles and chariots invaded agrarian tribes, resulting in the formation of nations consisting of both pastoral and agrarian tribes. The West originated from the Middle East and Greece is dominated by individualism to form individualistic feudal nations, while the East originated from India and China is dominated by collectivism to form collectivistic authoritarian nations. The stage is the split feudalism-authoritarian stage.

In the Iron Age to start modernity, abundant and high-quality iron allowed nations to expand into mega nations, such as mega empires, which produced ra- 
tionality to rule mega nations consistently and logically. In the West, rationality produced rule of law and liberty to form individualistic capitalist mega nations such as the Roman Empire and the capitalist nations in the nineteenth century before the highly developed industrialization in Europe. In the East, rationality produced rule of relation and division of professional to form collectivistic meritocracy mega nations.

In the highly developed Industrial Age in the twentieth century, affluence from industrialization provides all people enough wealth and education to establish democracy which literally means in Greek that power (kratos) belongs to the common people (demos). In democracy, power belongs to the common people instead of dictators, inherited kings-queens, and inherited aristocrats. Democracy does not mean individual liberal democracy only. The Industrial Revolution transforms capitalism into individual liberal democracy (individualism, rule of law, liberty, and affluence) for all people principally in individual liberty. Meanwhile, the Industrial Revolution transforms meritocracy into common professional democracy (collectivism, rule of relation, division of profession, and affluence) for all people principally in common wellbeing. Common professional democracy is conventionally called socialism.

Postmodernity derived from the Information Revolution provides information for diverse cultures. It is better to recognize, respect, and understand other cultures than to ignore, disrespect, and demonize other cultures. The Intelligence Revolution provides the sources of information and products from all places in the world, resulting in the interconnected world. The result is eusocial eu-modernity. The full-fledged eusociality includes interdependent democracies between individual liberal democracy and common professional democracy (rules of lawrelation, liberty-division-of-professional, affluence, diversity, and interdependence), the 12 international regional defense communities, interdependent production types (interdependent adventurous-consolidative production types), interdependent religions (interdependent imaginary parent-ruler guardian), and interdependent cares (interdependent multigenerational generativity-intergroup generosity).

In conclusion, the Auguste Comte's parallel human-civilizational developments in the early nineteenth century are broadened and updated for the twenty-first century. Each individual human develops from believing infancy to believe in parent as believing premodernity to believe in authoritative religion, to autonomous toddlerhood to explore as rational autonomous modernity to explore, to diverse childhood to learn diversity as diverse postmodernity to learn diversity, and to eusocial adulthood to establish eusociality by interdependent division of labor, multigenerational generativity, and intergroup generosity as eusocial eumodernity to establish eusociality by interdependent division of labor between individualism and collectivism, multigenerational generativity for long-term wellbeing, and intergroup generosity for long-distance wellbeing. The parallel developments between the human identity development and the civilizational 
identity development point to the direction of civilization to achieve eusocial eu-modernity as adulthood civilization.

\section{Conflicts of Interest}

The author declares no conflicts of interest regarding the publication of this paper.

\section{References}

Angus, D. et al. (2015). Limitations in Social Anticipation Are Independent of Imaginative and Theory of Mind Abilities in Children with Autism But Not in Typically Developing Children. Autism, 19, 604-612. https://doi.org/10.1177/1362361314537911

Anthony, D. (2010). The Horse, the Wheel, and Language: How Bronze-Age Riders from the Eurasian Steppes Shaped the Modern World. Princeton, NJ: Princeton University Press. https://doi.org/10.2307/j.ctt7sjpn

Arnett, J. (2000). Emerging Adulthood: A Theory of Development from the Late Teens through the Twenties. American Psychologist, 55, 469-480. https://doi.org/10.1037/0003-066X.55.5.469

Babones, S. (2017). American Tianxia: Chinese Money, American Power, and the End of History. Bristol: Policy Press. https://doi.org/10.1332/policypress/9781447336808.001.0001

Baron-Cohen, S., Leslie, A., \& Frith, U. (1985). Does the Autistic Child Have a Theory of Mind? Cognition, 21, 37-46. https://doi.org/10.1016/0010-0277(85)90022-8

Bar-Yosef, O. (2002). The Upper Paleolithic Revolution. Annual Review of Anthropology, 31, 363-393. https://doi.org/10.1146/annurev.anthro.31.040402.085416

Beam, J. (1978). I Can’t Play God Anymore. McCall's Magazine, January 1978, 154-158.

Bell, D. (2015). The China Model: Political Professionalism and the Limits of Democracy. Princeton, NJ: Princeton University Press.

Bloch, M. (2006). Why Religion Is Nothing Special But Is Central. Philosophical Transactions of the Royal Society B, 363, 1499. https://doi.org/10.1098/rstb.2008.0007

Bogin, B., \& Varea, C. (2016). Evolution of Human Life History. Evolution of Nervous Systems. In J. Kaas (Ed.), Evolution of Nervous Systems (pp. 37-50). Amsterdam: Elsevier. https://doi.org/10.1016/B978-0-12-804042-3.00103-2

Brueggemann, W. (2002). Reverberations of Faith: A Theological Handbook of Old Testament Themes. Louisville, KY: Westminster John Knox Press.

Buxton, R. G. A. (1999). From Myth to Reason? Studies in the Development of Greek Thought. Oxford: Oxford University Press.

Calarge, C., Andreasen, N., \& O'Leary, D. (2003). Visualizing How One Brain Understands Another: A PET Study of Theory of Mind. American Journal of Psychiatry, 160, 1954-1964. https://doi.org/10.1176/appi.ajp.160.11.1954

Carvalho, S. et al. (2012). Chimpanzee Carrying Behaviour and the Origins of Human Bipedality. Current Biology, 22, R180-R181. https://doi.org/10.1016/j.cub.2012.01.052

Castro, D., McLaughlin, M., \& Chivot, E. (2019). Who Is Winning the AI Race China, the EU or the United States? Center for Data Innovation, August 19, 2019.

https://www.datainnovation.org/2019/08/who-is-winning-the-ai-race-china-the-eu-orthe-united-states

Chan, P. et al. (2016). Theory of Mind Deficit Is Associated with Pretend Play Perfor- 
mance, But Not Playfulness, in Children with Autism Spectrum Disorder. Hong Kong Journal of Occupational Therapy, 28, 43-52. https://doi.org/10.1016/j.hkjot.2016.09.002

Chung, D. (2016a). The Basic Principles of Kin Sociality and Eusociality: Human Evolution. Natural Science, 8, 8-19. https://doi.org/10.4236/ns.2016.81002

Chung, D. (2016b). The Human Religious Evolution. Open Journal of Social Sciences, 4, 75-90. https://doi.org/10.4236/jss.2016.43013

Chung, D. (2017). Human Cultural Evolution: Postmodernity as Rational Global Diversity. Open Journal of Social Sciences, 5, 304-337. https://doi.org/10.4236/jss.2017.55022

Chung, D. (2018). The Eight Stages of Psychosocial Protective Development: Developmental Psychology. Journal of Behavioral and Brain Science, 8, 369-398. https://doi.org/10.4236/jbbs.2018.86024

Chung, D. (2019). The Evolution of Theisms: The Four Technological Revolutions and the Four Theistic Revolutions. Open Journal of Social Sciences, 7, 213-242. https://doi.org/10.4236/jss.2019.74018

Chung, D. (2020a). The Interdependent Coexistence of the Rational Civilizations: The Mental Origin of Civilizations. Journal of Behavioral and Brain Science, 10, 46-94. https://doi.org/10.4236/jbbs.2020.101004

Chung, D. (2020b). General Marxism by Production Dimension Model, Production Evolution, and Individualism-Collectivism Duality. Open Journal of Social Sciences, 8, 282336. https://doi.org/10.4236/jss.2020.86025

Cline, E. (2014). 1177 B.C.: The Year Civilization Collapsed. Princeton, NJ: Princeton University Press. https://doi.org/10.1515/9781400849987

Cohen, A., \& Hill, P. (2007). Religion as Culture: Religious Individualism and Collectivism among American Catholics, Jews, and Protestants. Journal of Personality, 75, 709-742. https://doi.org/10.1111/j.1467-6494.2007.00454.x

Cohen, A., Wu, M., \& Miller, J. (2016). Religion and Culture: Individualism and Collectivism in the East and West. Journal of Cross-Cultural Psychology, 47, 1236-1249. https://doi.org/10.1177/0022022116667895

Comte, A., \& Lenzer, G. (1998). Auguste Comte and Positivism the Essential Writings. Piscataway, NJ: Transaction Publishers.

Crespi, B., \& Douglas, Y. (1995). The Definition of Eusociality. Behavior Ecology, 6, 109115. https://doi.org/10.1093/beheco/6.1.109

Cunliffe, B. (2001). The Oxford Illustrated History of Prehistoric Europe. Oxford: Oxford University Press.

Curtis, G. (2016). Weak Opposition Makes Japan Look like a One-Party System. Financial Review, September 18, 2016.

Daly, H. (1999). Globalization versus Internationalization-Some Implications. Ecological Economics, 31, 31-37. https://doi.org/10.1016/S0921-8009(99)00087-7

Davies, P. (2010). Urban Religion and Rural Religion. In F. Stavrakopoulou, \& J. Barton (Eds.), Religious Diversity in Ancient Israel and Judah (pp. 103-115). New York: Continuum International Publishing Group.

Davies, R. (1998). Soviet Economic Development from Lenin to Khrushchev. Cambridge: Cambridge University Press. https://doi.org/10.1017/CBO9780511622335

Debeuf, K. (2019). Tribalization: Why War Is Coming. Bruxelles: Academic \& Scientific Publishers.

Dixson, A., \& Dixson, B. (2011). Venus Figurines of the European Paleolithic: Symbols of Fertility or Attractiveness? Journal of Anthropology, 2011, Article ID: 569120. https://doi.org/10.1155/2011/569120 
Domashneva, H. (2020). The Future of AI Depends on Asia. The Diplomat, February 29, 2020. https://thediplomat.com/2020/02/the-future-of-ai-depends-on-asia/

Dunbar, R. (1992). Neocortex Size as a Constraint on Group Size in Primates. Journal of Human Evolution, 22, 469-493. https://doi.org/10.1016/0047-2484(92)90081-J

Dunbar, R. (2016). The Social Brain Hypothesis and Human Evolution. In Oxford Research Encyclopedia of Psychology. Oxford: Oxford University Press. https://doi.org/10.1093/acrefore/9780190236557.013.44

Durkheim, E. (1997). The Division of Labour in Society. New York: Free Press.

Erikson, E., \& Erikson, J. (1998). The Life Cycle Completed. New York: W. W. Norton \& Company.

Etzioni, A. (2004). How Patriotic Is the Patriot Act? Freedom versus Security in the Age of Terrorism. New York: Routledge. https://doi.org/10.4324/9780203997130

Ferguson, N. (2008). Team “Chimerica”. The Washington Post, November 17, 2008.

Finch, C., \& Stanford, C. (2004). Meat-Adaptive Genes and the Evolution of Slower Aging in Humans. The Uarterly Review of Biology, 79, 3-50. https://doi.org/10.1086/381662

Fisher, M. (2018). The Weaknesses in Liberal Democracy That May Be Pulling It Apart. The New York Times, November 1.

https://www.nytimes.com/2018/11/01/world/americas/democracy-brazil-populism.html

Fukuyama, F. (1992). The End of History and the Last Man. New York: Free Press.

Giddens, A. (1991). Modernity and Self-Identity: Self and Society in the Late Modern Age. Palo Alto, CA: Stanford University Press.

Grossmann, I., \& Kross, E. (2010). The Impact of Culture on Adaptive versus Maladaptive Self-Reflection. Psychological Science, 21, 1150-1157. https://doi.org/10.1177/0956797610376655 http://pss.sagepub.com/content/early/2010/07/12/0956797610376655

Guo, Q., Liu, Z., Li, X., \& Qiao, X. (2018). Indulgence and Long Term Orientation Influence Prosocial Behavior at National Level. Frontiers in Psychology, 9, 1798. https://doi.org/10.3389/fpsyg.2018.01798

Haakonssen, K. (1996). Natural Law and Moral Philosophy: From Grotius to the Scottish Enlightenment. Cambridge: Cambridge University Press. https://doi.org/10.1017/CBO9781139172905

Hamlin, J. K., Mahajan, N., \& Wynn, K. (2013). Not Like Me = Bad Infants Prefer Those Who Harm Dissimilar Others. Psychological Science, 24, 589-594. https://doi.org/10.1177/0956797612457785

Henrich, J. (2015). Culture and Social Behavior. Current Opinion in Behavioral Sciences, 3, 84-89. https://doi.org/10.1016/j.cobeha.2015.02.001

Hetzron, R. (1997). The Semitic Languages. London/New York: Routledge.

Heyes, C. (2015). Animal Mindreading: What's the Problem? Psychonomic Bulletin \& Review, 22, 313-327. https://doi.org/10.3758/s13423-014-0704-4

Hofstede, G. et al. (2010). Cultures and Organizations: Software of the Mind. London: McGraw-Hill.

Hogan, J., \& Vaccaro, T. (2006). Internationalizing the History of Developmental Psychology. New York: New York University Press.

Honneth, A. (1987). Enlightenment and Rationality. The Journal of Philosophy, 84, 692699. https://doi.org/10.5840/jphil1987841119

Hundt, D., \& Uttam, J. (2017). Varieties of Capitalism in Asia: Critical Studies of the Asia-Pacific. London: Palgrave Macmillan. https://doi.org/10.1057/978-1-349-58974-6 
Huntington, S. (1996). The Clash of Civilizations and the Remaking of World Order. New York: Simon \& Schuster.

Jiang, G., Lo, T., \& Garris, C. (2012). Formation and Trend of Guanxi Practice and Guanxi Phenomenon. International Journal of Criminology and Sociology, 1, 207-220. https://doi.org/10.6000/1929-4409.2012.01.19

Joas, H., \& Bellah, R. (2012). The Axial Age and Its Consequences. Cambridge, MA: Harvard University Press. https://doi.org/10.4159/harvard.9780674067400

Kapogiannis, D. et al. (2009). Cognitive and Neural Foundations of Religious Belief. Proceedings of the National Academy of Sciences, 106, 4876-4881.

https://doi.org/10.1073/pnas.0811717106

Kapogiannis, D. et al. (2014). Brain Networks Shaping Religious Belief. Brain Connectivity, 4, 70-79. https://doi.org/10.1089/brain.2013.0172

Kazin, M., Edwards, R., \& Rothman, A. (2010). The Princeton Encyclopedia of American Political History Volume 2 (p. 142). Princeton, NJ: Princeton University Press. https://doi.org/10.1515/9781400833566

Kim, P., Coxworth, J., \& Hawkes, K. (2012). Increased Longevity Evolves from Grandmothering. Proceedings of the Royal Society B: Biological Sciences, 279, 4880-4884. https://doi.org/10.1098/rspb.2012.1751

Krupenye, C. et al. (2016). Great Apes Anticipate That Other Individuals Will Act According to False Beliefs. Science, 354, 110-114. https://doi.org/10.1126/science.aaf8110

Lee, K. (2018). AI Superpowers: China, Silicon Valley, and the New World Order. Boston, MA: Houghton Mifflin Harcourt.

Lewis-Williams, D. (2002). The Mind in the Cave: Consciousness and the Origins of Art. London: Thames \& Hudson.

Lovejoy, C. (2009). Reexamining Human Origins in Light of Ardipithecus ramidus. Science, 326, 74. https://doi.org/10.1126/science.1175834

Lukas, S. (2013). Postmodernism. In R. Jon McGee, \& R. L. Warms (Eds.), Theory in Social and Cultural Anthropology: An Encyclopedia (Vol. 2, pp. 639-645). Thousand Oaks, CA: SAGE.

Lyotard, J. (1984). The Postmodern Condition: A Report on Knowledge. Minneapolis, $\mathrm{MN}$ : University of Minnesota Press.

Ma, W., Feng, R., Hu, R., Xi, J., Fox, E., \& Ding, X. (2016). Toward the Theoretical Constructs of East Asian Cultural Psychology. In C. Roland-Lévy, P. Denoux, B. Voyer, P. Boski, \& W. K. Gabrenya Jr. (Eds.), Unity, Diversity and Culture. Proceedings from the 22nd Congress of the International Association for Cross-Cultural Psychology. https://scholarworks.gvsu.edu/iaccp papers/228

Makridakis, S. (2017). The Forthcoming Artificial Intelligence (AI). Revolution: Its Impact on Society and Firms. Futures, 90, 46-60.

https://doi.org/10.1016/j.futures.2017.03.006

Marx, K. (1990). Capital: A Critique of Political Economy (Vol. 1, Trans. Ben Fowkes). New York: Penguin.

Masse, M. (2008). Bailout Marks Karl Marx’s Comeback. Canada Financial Post, September 29, 2008.

McAdams, D., \& De St. Aubin, E. (1992). A Theory of Generativity and Its Assessment through Self-Report, Behavioral Acts, and Narrative Themes in Autobiography. Journal of Personality and Social Psychology, 62, 1003-1015.

https://doi.org/10.1037/0022-3514.62.6.1003

McDonald, M. (2012). Evolution and the Psychology of Intergroup Conflict: The Male 
Warrior Hypothesis. Personality and Social Psychology Bulletin, 32, 1559-1572.

Meacham, J. (2009). We Are All Socialists Now. Newsweek, February 62009.

Muhly, J. (2003). Metalworking/Mining in the Levant. In S. Richard (Ed.), Near Eastern Archaeology: A Reader (pp. 174-183). Winona Lake, IN: Eisenbrauns.

Newar, S. (2016). Dalits of Hinduism: Dharma's Fight for Lost Children. New Delhi: Agniveer.

Nichols, T. (2017). The Death of Expertise: The Campaign against Established Knowledge and Why It Matters. New York: Oxford University Press.

Nisbett, R. (2004). The Geography of Thought: How Asians and Westerners Think Differently...and Why. New York: Free Press.

Nisbett, R. et al. (2001). Culture and Systems of Thought: Holistic versus Analytic Cognition. Psychological Review, 108, 291-310. https://doi.org/10.1037/0033-295X.108.2.291

Norenzayan, A. et al. (2016). The Cultural Evolution of Prosocial Religions. Behavioral and Brain Sciences, 39, e1. https://doi.org/10.1017/S0140525X15000655

Norenzayan, A., Gervais, W., \& Trzesniewski, K. (2012). Mentalizing Deficits Constrain Belief in a Personal God. PLoS ONE, 7, e36880.

https://doi.org/10.1371/journal.pone.0036880

OECD (2019). PISA 2018 Results. https://www.oecd.org/pisa/publications/pisa-2018-results.htm

Orton, J. (2009). Semiconductors and the Information Revolution: Magic Crystals That Made IT Happen (pp. 103-105). Cambridge, MA: Academic Press.

Oyserman, D., Coon, H., \& Kemmelmeier, M. (2002). Rethinking Individualism and Collectivism: Evaluation of Theoretical Assumptions and Meta-Analyses. Psychological Bulletin, 128, 3-72. https://doi.org/10.1037/0033-2909.128.1.3

Panitch, L. (2009). Thoroughly Modern Marx. Foreign Policy, September 30, 2009.

Peoples, H., Duda, P., \& Marlowe, F. (2016). Hunter-Gatherers and the Origins of Religion. Human Nature, 27, 261-282. https://doi.org/10.1007/s12110-016-9260-0

Peters, R. (2006). Ageing and the Brain. Postgraduate Medical Journal, 82, 84-88. https://doi.org/10.1136/pgmj.2005.036665

Roosevelt, E. et al. (2001). Universal Declaration of Human Rights. Bedford, MD: Applewood Book.

Scott, F., \& Baron-Cohen, S. (1996). Imagining Real and Unreal Objects: Evidence of a Dissociation in Autism. Journal of Cognitive Neuroscience, 8, 400-411. https://doi.org/10.1162/jocn.1996.8.4.371

Shan, W. (2019). The Unwinnable Trade War. Foreign Affairs, 98-6.

Shilling, C., \& Mellor, P. (1998). Durkheim, Morality and Modernity: Collective Effervescence, Homo Duplex and the Sources of Moral Action. British Journal of Sociology, 49, 193-209. https://doi.org/10.2307/591309

Slater, C. L. (2003). Generativity versus Stagnation: An Elaboration of Erikson's Adult Stage of Human Development. Journal of Adult Development, 10, 53-65. https://doi.org/10.1023/A:1020790820868

Smith M. (2001). Untold Stories: The Bible and Ugaritic Studies in the Twentieth Century. Peabody, MA: Hendrickson Publishers.

Steadman, L., Palmer, C., \& Tilley, C. (1996). The Universality of Ancestor Worship. Ethnology, 35, 63-76. https://doi.org/10.2307/3774025

Stern, E. (2001). Archaeology of the Land of the Bible, Volume II the Assvrian. New York: 
Doubleday.

Swanson, G. (1960). The Birth of the Gods: The Origin of Primitive Belief. Ann Arbor, MI: University of Michigan Press. https://doi.org/10.3998/mpub.6484

Tan, C., \& Geng, Y. (2005). India and China: Twenty Centuries of Civilization Interaction and Vibrations (p. 128). Ann Arbor, MI: University of Michigan Press.

Taylor, M. (1999). Imaginary Companions and the Children Who Create Them. New York: Oxford University Press.

Taylor, M. et al. (2004). The Characteristics and Correlates of Fantasy in School-Age Children: Imaginary Companions, Impersonation, and Social Understanding. Developmental Psychology, 40, 1173-1187. https://doi.org/10.1037/0012-1649.40.6.1173

The United Nations (2019). Member States. https://www.un.org/en/member-states

The World Bank Group (2018). China: Systematic Country Diagnostic. http://documents.worldbank.org/curated/en/147231519162198351/pdf/China-SCD-pu blishing-version-final-for-submission-02142018.pdf

Tsai, J. (2007). Ideal Affect: Cultural Causes and Behavioral Consequences. Perspectives on Psychological Science, 2, 242-259. https://doi.org/10.1111/j.1745-6916.2007.00043.x

Tsai, J., Miao, F., \& Seppala, E. (2007). Good Feelings in Christianity and Buddhism: Religious Differences in Ideal Affect. Personality and Social Psychology Bulletin, 33, 409421. https://doi.org/10.1177/0146167206296107

Tsutaya, T., \& Yoneda, M. (2013). Quantitative Reconstruction of Weaning Ages in Archaeological Human Populations Using Bone Collagen Nitrogen Isotope Ratios and Approximate Bayesian Computation. PLoS ONE, 8, e72327.

https://doi.org/10.1371/journal.pone.0072327

Turner, J., \& Reynolds, K. (2010). The Story of Social Identity. In T. Postmes, \& N. Branscombe (Eds.), Rediscovering Social Identity: Core Sources. New York: Psychology Press.

US News \& World Report (2019). Best Global Universities Rankings. US News \& World Report. https://www.usnews.com/education/best-global-universities/rankings

Vogel, E. (2011). Deng Xiaoping and the Transformation of China. Cambridge, MA: The Belknap Press of Harvard University Press. https://doi.org/10.4159/harvard.9780674062832

Wadsworth, B. (2004). Piaget's Theory of Cognitive and Affective Development: Foundations of Constructivism. London: Longman Publishing.

Wellman, H. M., \& Liu, D. (2004). Scaling of Theory-of-Mind Tasks. Child Development, 75, 523-541. https://doi.org/10.1111/j.1467-8624.2004.00691.x

White, T. D. et al. (2009). Ardipithecus ramidus and the Paleobiology of Early Hominins. Science, 326, 75-86. https://doi.org/10.1126/science.1175802

Wilson, E. O. (2012). The Social Conquest of the Earth. New York: W. W. Norton \& Company.

Wrangham, R. (2018). Two Types of Aggression in Human Evolution. Proceedings of the National Academy of Sciences, 115, 245-253. https://doi.org/10.1073/pnas.1713611115

Wright, R. (2009). The Ancient Indus: Urbanism, Economy, and Society. Cambridge: Cambridge University Press.

Wu, K. (2020). The 2010s Were the Hottest Decade on Record. What Happens Next? Smithsonian Magazine, January 16, 2020.

Wunn, I. (2000). Beginning of Religion. Numen, 47, 417-453.

https://doi.org/10.1163/156852700511612 
Yuki, M. et al. (2005). Cross-Cultural Differences in Relationship- and Group-Based Trust. Personality and Social Psychology Bulletin, 31, 48-62. https://doi.org/10.1177/0146167204271305

Zatrev, J. (2014). The Co-Evolution of Human Intersubjectivity, Morality, and Language. In D. Dor, C. Knight, \& J. Lewis (Eds.), The Social Origins of Language (pp. 249-266). Oxford: Oxford University Press.

Zhang, C. (2013). The Evolution of Rationality and Modernity Crisis. Sociology Mind, 3, 179-184. https://doi.org/10.4236/sm.2013.32024

Zhang, D. (2018). The Concept of “Community of Common Destiny” in China's Diplomacy: Meaning, Motives and Implications. Asia \& the Pacific Policy Studies, 5, 196-207. https://doi.org/10.1002/app5.231 